Canadian

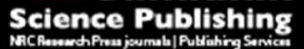

Canadian Journal of Civil Engineering Revue canadienne de génie civil

\title{
Fruit and vegetable wash-water characterization, treatment feasibility study and decision matrices
}

\begin{tabular}{|r|l|}
\hline Journal: & Canadian Journal of Civil Engineering \\
\hline Manuscript ID & cjce-2017-0214.R1 \\
\hline Manuscript Type: & Article \\
\hline Date Submitted by the Author: & 23-Jun-2017 \\
\hline $\begin{array}{r}\text { Complete List of Authors: } \\
\text { Is the invited manuscript for } \\
\text { consideration in andi, Gurvinder; University of Guelph, School of Engineering } \\
\text { Issue? : }\end{array}$ & $\begin{array}{l}\text { W/A } \\
\text { Warriner, Keith; University of Guelph, Dept. of Food Science }\end{array}$ \\
\hline Keyword: & $\begin{array}{l}\text { fresh-cut fruits and vegetables, wash-water, treatment technology, solids } \\
\text { reduction, agri-food sector }\end{array}$ \\
\hline &
\end{tabular}

SCHOLARONE ${ }^{\text {m }}$

Manuscripts 


\section{FRUIT AND VEgETABLE WASH-WATER CHARACTERIZATION, TREATMENT FEASIBILITY STUDY AND DECISION MATRICES}

Gurvinder S. Mundi ${ }^{1}$, Richard G. Zytner ${ }^{1^{*}}$ and Keith Warriner ${ }^{2}$

University of Guelph, School of Engineering ${ }^{1}$ and Department of Food Science ${ }^{2}$

Guelph, Ontario

*corresponding author

On average, it is estimated that up to 5 liters of wastewater is generated per $\mathrm{kg}$ of produce in post-harvest processing of fruit, leafy greens and root vegetables. The

12 typical wastewater parameters vary in concentration (solids content, COD, BOD, 13 nitrogen, phosphorus) based on the produce being processed. The challenge for producers and regulators is that the selection of the appropriate treatment technology is challenging, so decision matrices were developed to narrow down the treatment selections. Wash-waters for different types of fruit and vegetables from two different operation types, washing only vs. washing and processing. Bench-scale treatments selected for testing included settling, coagulation and flocculation with settling, centrifuge, dissolved air flotation, electrocoagulation, screening, and hydrocyclone. The developed decision matrices summarize the removal effectiveness of the different treatments for typical wastewater parameters and serve as a reference tool in understanding wash-water treatment technologies and their effectiveness in treating various wash-waters.

keywords: fresh-cut fruits and vegetables, wash-water, treatment technology, solids reduction

\section{Introduction}

The fresh-cut fruit and vegetable sector continues to grow due to increasing demand for fresh yet convenient ready-to-eat foods (Klaiber et al. 2005; Lehto et al.

32 2014; Alarcón-Flores et al. 2014). In Canada, the farm-gate value of fruits and 33 vegetable increased by $4 \%$ from 2014 to $\$ 1.9$ billion in 2015 , where Ontario accounted 
34 for $43 \%$ of all total vegetables grown in Canada (Statistics Canada 2016). This is 35 largely due to the many health benefits of fruits and vegetables, such as preventing cardiovascular diseases and reducing the risk of certain cancers (Soerjomataram et al.

37 2010; Bhupathiraju and Tucker 2011; Stefler et al. 2016). Delivering fruits and vegetables to the consumers table requires large volumes of resources (water, nutrients and environment) and energy (input to grow, harvest and transport). For example, large facilities may use up to $100 \mathrm{~m}^{3}$ of potable water per day for washing and processing needs (Casani et al. 2005).

Following harvest, produce is washed to remove soils, fertilizers and pesticides. Additional processing stages, such as cutting, peeling, sanitization and packaging, are added at some facilities. Water is also used for transporting product with in the facility and for in plant sanitization. The result is large volumes of potable waters are used, water (Casani et al. 2005; Hafez et al. 2007; Kato et al. 2013; Kern et al. 2006; Lehto et al. 2014, 2009; Mundi 2013; Mundi and Zytner 2015; Ölmez and Kretzschmar 2009). thereby generating equally large amounts of wastewater, typically referred to as washThis wash-water may contain heavy loads of solids in the form of dissolved and particulate matter, high levels of organic matter and solids from peeling processes, elevated levels of chemical and biochemical oxygen demand (COD and BOD), nutrients (nitrogen \& phosphorus) and pathogens. These water quality parameters normally exceed regulations set by Ministry of the Environment and Climate Change (MOECC), provincial and municipal governments, negatively impacting surrounding water courses, ecosystems and wastewater treatment plants. (Kern et al. 2006; Lehto et al. 2009 and 2014; Mundi 2013; Mundi and Zytner 2015). Based on the quality of wash-water, 
57 environmental regulations concerning wash-water treatment are becoming stringent all 58 the time. water system, several batches of produce are often washed with the same water without any in-between treatment or have recharge rates that vary between 0 to $40 \%$

62 per/h (Salomonsson et al., 2014; Shortt, R \& Nemeth, D., personal communication 2013-2016; Warriner et al. 2012). After its useful life, wash-waters are disposed of as wastewater. Wastewater from the fruit and vegetable washing and/or processing 65 industry is often interchangeably referred to as wash-water instead of gray water, as it does not contain contaminants commonly found in domestic wastewater, such as feces

67 and urine (Eriksson et al. 2002). As such, "wash-water" will be used herein when referring to wastewater from fruit and vegetable washing and/or processing.

Review of the literature shows that some work has been done on understanding the physical, chemical, and microbial qualities of wash-water and wastewater from different fruit and vegetable washing and processing operations (Casani et al. 2005; Hafez et al. 2007; Kato et al. 2013; Kern et al. 2006; Lehto et al. 2014, 2009; Ölmez and Kretzschmar 2009; Mundi 2013; Mundi and Zytner 2015). However, due to the large variation in values, growers still ask the question, what wash-water treatment process will work best for them. Best can be referred to a minimal treatment that allows discharge on their fields, to full treatment that allows recycling with minimal health risk.

77 Given that soil washing and processing operations are highly variable due to soil and environmental conditions, along with changing crops, there is still limited information on

79 the topic and datasets world-wide. As such, research efforts are needed to explore best 
management practices (BMP) for the treatment of wash-water with the potential for water reuse, which starts with investigating and characterizing wash-waters from different operations.

The first objective of this research was to characterize wash-water from different fruit and vegetable washing and/or processing facilities. Wash-water samples were collected from various fruit and vegetable facilities in southern Ontario and analyzed for typical water quality parameters. This allowed identification of trends and commonalities in the water quality parameters, understand removal efficiencies of current BMP for solids, nutrients (nitrogen and phosphorus), COD, BOD, and pathogens. The second objective of the study was to assess the effectiveness of various wastewater treatment technologies in reducing solids in raw wash-waters. Bench-scale experiments were conducted on all wash-waters to measure solids reduction efficiencies and the corresponding impact on the removal of secondary contaminants, such as $C O D, B O D$, nitrogen, phosphorus, and pathogens.

Bench-scale testing consisted of screening (sieve), hydrocyclone, settling with coagulation and flocculation (C\&F), centrifuge, dissolved air flotation (DAF) and electrocoagulation (EC). The primary focus was on the removal of solids. However, other water quality parameters were monitored for completeness. For ease of interpretation of results, averaged reduction values were converted to effectiveness ratings ranging from Poor, $\mathrm{P}(<40 \%$ removal), Satisfactory, S $(40-60 \%$ removal), Good, G $(61-75 \%$ removal), Very Good, VG $(76-90 \%$ removal), to Excellent, E (>90\% removal). Upon completing the analysis, decision matrices were developed to highlight treatment effectiveness for different fruits and vegetables according to the operation 
103 type (washing only vs. washing and processing) to provide the best quality water fit for 104 the intended purpose. These decision matrices, which are considered rudimentary, 105 address a deficiency in the literature as it will help producers and processor determine 106 which technology they should consider to treat the wash-water they generate.

102 Background

Many treatment technologies exist to remove solids and other contaminants from wastewater like coagulation and flocculation, activated sludge treatment and sand

111 filtration. However, when looking at the literature for specific examples in the agri-food 112 industry, there are limited applications in the fresh-cut fruit and vegetable sector (Shortt, 113 R. \& Nemeth, D., personal communication, 2013-2016; Mundi 2013; Mundi and Zytner 114 2015). The generic systems that are available use a combination of physical, chemical 115 and biological methods, although most are costly and difficult to maintain. In any case, 116 many are beyond the requirements of fresh produce processors. Increasing stringent 117 standards along with water costs have increased the need for on-site wastewater 118 treatment. Compounding the problem is that most of these facilities try to limit the 119 budget on treatment processes. By understanding the behavior of bench-scale 120 treatments with different wash-water types (washing and/or processing), one can 121 determine the effectiveness of treatments, allowing for implementation of BMPs. The 122 level of treatment and removal of constituents will dictate the end use of the treated 123 waters.

124 In total, six different water treatment systems were explored after discussions 125 with Ontario Ministry of Agriculture, Food, and Rural Affairs (OMAFRA) regarding what 
126 growers typically adopt as generally cost-effective, easily implemented and effective in

127 reducing solids. The six processes are screening (sieve), hydrocyclone, centrifuge, 128 settling with coagulation and flocculation, flotation, and electro-coagulation.

\subsection{Screening (Sieve)}

Screening is the first step in treating any wash-water as it removes large objects

132 and particles from the wash-water stream that are generated due to washing and 133 processing of fruits and vegetables (Ljunggren 2006; Valta et al. 2015). Screening can 134 be done with a course and/or fine mesh $(200-50 \mu \mathrm{m})$ to retain large particles (Lee 135 2007). Screening is an elementary, simple, and cost-effective step in treating any 136 wastewater, but requires additional investigation to identify when it works best for agri137 food wash-waters (Ljunggren 2006).

\subsection{Hydrocyclone}

Unlike screening or sieve, a hydrocyclone does not have a physical separator.

141 Instead, a vortex is created via a pressure differential inside the hydrocyclone allowing 142 heavy solids such as sand/silt to be ejected at the underflow of hydrocyclone. 143 Hydrocyclones have been used in many applications of solid-liquid and liquid-liquid 144 separation (oil and water) (Son et al. 2016). Its simplicity of operation, lack of moving 145 parts (other than the pump) and low maintenance costs make it advantageous to use in

146 small-scale operations or low-technology processing, where it can easily be fitted to an 147 existing pump (Bain and Morgan 1983; Hwang et al. 2012; Soccol and Botrel 2004; 148 Yang et al. 2013). Literature review did not show any commercial applications specific 
149 to fresh produce washing/processing. However, hydrocyclones have been 150 conventionally used for potato starch separation, grit removal from wastewaters, and in 151 the wet milling industry for starch-protein separation (Verberne 1997; Mansour152 Geoffrion et al. 2010; Singh and Eckhoff 1995).

\subsection{Centrifuge}

Another form of mechanical solid-liquid separation method is centrifugation. The high spin rate separates the particles from the water. Various types of centrifuges are 157 available for sedimentation and filtration as applications exist in all types of industries. 158 Recent developments of centrifugation technology are highlighted by Anlauf (2007). For 159 this study, the focus will be on sedimentation type centrifuges, where high-speed 160 rotation forces are used to separate solids from liquid in a rotating cylindrical bowl 161 (USEPA 2000). Centrifuges have been used for many decades to dewater or thicken 162 solids from anaerobic digestion for subsequent composting or landfilling (Park et al. 163 2011). Sometime polymers are added to improve separation efficiencies. Dewatering 164 also reduces the volume of solids waste, which affects transportation costs for disposal 165 or possible use as a by-product (e.g., cattle feed). High solid reduction efficiencies and 166 small footprint design allows for use in multiple applications and is often preferred when 167 dewatering solids (Norton and Wilkie 2004).

\subsection{Coagulation and Flocculation Process (C\&F)}

C\&F is widely used in the wastewater and food industry to precipitate out

171 particulate and dissolved matter (Hafez et al. 2007; Van Haute et al. 2015). The three 
172 types of coagulants commonly used in C\&F are metal salts (alum or ferric sulfate), 173 polyelectrolytes (polymers) which are effective but expensive, and natural (chitosan)

174 (Renault et al. 2009; Ahmad et al. 2004). C\&F works on the principle of neutralizing the 175 wash-water particles that are negatively charged, which causes destabilization of 176 repulsive forces and permits flocculation, agglomeration and formation of particles.

177 C\&F works best for solids with a specific gravity greater than water to remove the 178 particles (Van Haute et al. 2015; Miranda et al. 2013; Sahu and Chaudhari 2013). 179 However, there are challenges when the specific gravity is close to 1, like carrot peels 180 (Mundi and Zytner 2015).

\subsection{Sedimentation (Settling)}

Settling can provide effective means of reducing solids content. It may also be used as a pre-treatment for DAF system or membrane filtration (Valta et al. 2015;

185 Khiadani et al. 2014). Many different types of settling tanks and configuration are 186 available on the market, including inclined (plate and tube) settlers (USEPA 1999). 187 Most applications make the use of settling ponds or long rectangular settling tanks, due 188 to cost and treatment effectiveness. Conventional settling treatment methods occupy a 189 large footprint, however this can be overcome by inclined plate settlers (Gregory and 190 Edzwald 2011; USEPA 1999). The plate settlers increase the area available for settling 191 thus increasing the discrete settling of particles. Sedimentation is essential for grit 192 removal and larger particulate matter and can be one of the most cost effective 193 treatments methods to date (Kern et al. 2006). Combined with the C\&F process, 194 settling can provide high quality treated waters. 


\subsection{Dissolved Air Flotation (DAF)}

Flotation is a clarification process with the simple principle of causing the solid particles in the wastewater to rise to the top of a flotation tank with the aid of fine air bubbles that are produced at the inlet of the flotation tank. Compressed air is the main agent of use for flotation. DAF is very good at removing low density material that may not settle easily. C\&F principles can also be used for DAF as they serve to destabilize

202 particles present in the wash-water and most importantly to convert dissolved organic 203 matter into particulate matter (Gregory and Edzwald 2011). Optimum coagulation 204 conditions are necessary for efficient removal of particles as is the case in 205 sedimentation. Both Teixeira and Rosa (2007) and Han and Kim (2000) have shown 206 C\&F with DAF to be superior when compared to C\&F with Settling due to DAF's ability 207 to remove cryptosporidium and algae. Mundi and Zytner (2015) showed that DAF was 208 an effective technology for removing carrot peelings from wash-water.

\subsection{Electrocoagulation (EC)}

Electrocoagulation is an emerging technique being utilized by agro-industry

212 wastewater, including food industry (Drogui et al. 2008; Kabdaşlı et al. 2012; Qasim and 213 Mane 2013). Electrocoagulation applies an electoral current to the wastewater through 214 aluminum or iron electrodes, which destabilizes the negative charge as done in 215 coagulation, and allows for the flocculation of particles. More specifically, the electrodes 216 are sacrificial and generate aluminum hydroxide $\left(\mathrm{Al}(\mathrm{OH})_{3}\right)$. The generation of hydrogen 217 causes the floc to float. This technology possesses many advantages such as in situ 
218 coagulation (minimal chemical use), easy installation, odour \& colour removal, lower 219 secondary pollutions, ability to reduce microorganism loadings, and most importantly 220 low residence times (Chopra 2011; Drogui et al. 2008).

221

2223 Methods and Materials

The study was conducted in southern Ontario, Canada. Samples were collected

224 from 14 facilities processing various types of fruits and vegetables as noted in Table 1.

225 The samples were collected post processing and at various locations within the

226 processing stream, including soil washing, cutting and/or peeling. Some facilities also

227 had on-site treatment systems, so pre- and post-treatment samples were also collected.

228 Table 1 provides clarification on the different type and number of samples collected at

229 each facility, type of product washed or processed, and facility codes, which will be

230 used here on. As such, the number of samples for each facility varied from 2 to 16,

231 giving a total of 83 samples collected. The 83 samples also had duplicates, where each

232 sample was characterized by 20 different analyses resulting in a total of 26 water quality

233 parameters for a total of approximately $3,000(83 \times 2 \times 20)$ data points. For facility $\mathrm{C} 1$ and

234 MV2, the samples were not assessed for all 20 water quality parameters due to

235 changes in the lab procedures. For all 14 facilities, raw wash-water samples were

236 subjected to six bench-scale treatments as noted in Section 2, which were also

237 characterized for the suite of water quality parameters, generating approximately 19,000

$238(83 \times 2 \times 20 \times 6)$ data points.

239 Approximately 2 litres $(L)$ of sample was collected at each sampling point for 240 determining water quality parameters. The samples were tested immediately upon 
241 return to the lab or within 24 hours. Treatment testing required about $40 \mathrm{~L}$ of wash-

242 water from each sampling point per sampling visit. When possible, fresh wash-water

243 was used during bench-scale treatment testing. For additional testing, wash-waters

244 were stored in laboratory refrigerator, set at $4{ }^{\circ} \mathrm{C}$ until use for testing.

245

246

\subsection{Wash-Water Characterization and Bench-scale Testing}

All wash-waters were analyzed before and after treatment, when possible, for typical water quality parameters. See Figure 1 for process flow diagram of the study.

249 Table 2 shows the water quality parameters that highlight the physical, chemical, 250 biological and microbiological properties of the wash-water. Table 2 also shows abbreviated names of water quality parameters which will be used from hereon, i.e., TS

252 for total solids. All samples were tested based on the procedures listed in the Standard Methods for Examination of Water and Wastewater, 22 ${ }^{\text {nd }}$ Edition (Rice et al. 2012).

Statistical summaries were computed on collected water quality parameters such as averages, median, standard deviation, minimum and maximum values for the

256 different categories of wash-waters. The raw water quality parameters of wash-water 257 and the corresponding treatments (Jar test, DAF, etc.) will be compared in terms of 258 reduction efficiencies. Reduction efficiency is represented by formula, $\left(\left(\mathrm{C}_{\mathrm{i}}-\mathrm{C}_{\mathrm{f}}\right) / \mathrm{Ci}\right)$ * 100 , 259 where $C_{i}$ is the initial concentration and $C_{f}$ is the final concentration. These reduction 260 efficiencies allow the calculation of reduction achieved in each water quality parameters 261 for the different treatments to better understand solids reduction. 
$264500 \mathrm{~mL}$ of wash-water sample onto a standard soil sieve of $100 \mu \mathrm{m}$ size, placed on top 265 of a $1 \mathrm{~L}$ glass beaker. Clarified samples were assed for appropriate parameters. The 266 test was used to understand the reduction in solids from screening of wash-waters. The 267 hydrocyclone experiment used approximately $4 \mathrm{~L}$ of well mixed wash-water sample 268 pumped at a flowrate of $1.3 \mathrm{~L} / \mathrm{min}$ to a $48 \mathrm{~mm}$ diameter of acrylic polymer 3-D printed 269 hydrocyclone. The apex and vortex finder of the hydrocyclone were 4 and $6.7 \mathrm{~mm}$ in 270 diameter, respectively. Centrifugation was done using a GS-6R Centrifuge (Gh-3.7 Horizontal Rotor).

272 The test procedure consisted of using two $250 \mathrm{~mL}$ centrifuge bottles for per wash-water 273 sample at $1801 \times \mathrm{G}(3,500 \mathrm{rpm})$ for 3 minutes. Both bottles were weighed and 274 corrected to have equal mass to ensure balanced operation of the centrifuge machine. 275 The clarified samples were decanted from the top and assessed for water quality 276 parameters. test apparatus from Phipps \& Bird Stirrer, Model 7790-400. Six jars were filled with 500 $279 \mathrm{~mL}$ sample of wash-water each, five of which were dosed with coagulant ranging in concentration $(1-400 \mathrm{mg} / \mathrm{L})$ of prepared coagulant mix, with the $6^{\text {th }}$ jar as the control.

281 The wash-water was stirred for $1 \mathrm{~min}$ at $100 \mathrm{rpm}$ for rapid mixing to dissolve the added 282 coagulant and $10 \mathrm{~min}$ at $30 \mathrm{rpm}$ for slow mixing to allow flocculation of particles. The 283 formed flocs settled for 20 min after which the upper $100 \mathrm{~mL}$ were decanted from the jar 284 using a pipette and analyzed for turbidity. The same experiment was executed a total of 285 four times to assess the four types of coagulants as noted below. The coagulant type 
286 and dosage yielding the best result as measured by turbidity was repeated using $1 \mathrm{~L}$ 287 wash-water sample to produce $400 \mathrm{~mL}$ of decanted sample for water quality analysis.

The four coagulants explored in this study consisted of Nalco ULTRION 8187 289 (Aluminum Chloride Hydroxide), Chitosan (polysaccharide from shrimp shells), Sigma290 were only explored on $\mathrm{C} 1$ facility's wash-waters as the performance was poor.

The DAF systems composed of two custom built graduated cylinders, which 294 acted as the reaction chambers and a pressure vessel for providing air-water mixture. 295 Tap water was pressurized to $70 \mathrm{psi}$ in $10 \mathrm{~L}$ vessel for 10 minutes and a $50 \%$ recycle rate was used on $1 \mathrm{~L}$ wash-water sample held for 10 minutes. The recycle rate refers to the volume of water under pressure, held in the $10 \mathrm{~L}$ vessel that will be released to the reaction chamber to cause flotation. After which the samples were extracted from middle of the graduated cylinder and assessed for water quality parameters.

Electrocoagulation bench scale experiments were performed with two different 301 setups. Initially a small version of the experiment was conducted in a $100 \mathrm{~mL}$ reactor, which was later improved to $500 \mathrm{~mL}$ reactor to process larger volume of clarified sample. Both setups consisted of utilizing aluminum electrodes or plates (second setup) in a reactor (beaker) to allow the wash-water sample to be charged with DC current. The range of voltages and currents were set using a Solartron Impedance-phase Analyzer. 306 The reaction surface areas were 1.571 and $575.1 \mathrm{~cm}^{2}$ with current densities of 54 and $3070.35 \mathrm{~A} / \mathrm{m}^{2}$ for the small and big experiment setups, respectively. Considering the 308 reactor volume, the reaction time of 30 and 10 mins, the corresponding power 
309 consumption is 6.8 and $0.27 \mathrm{KWh} / \mathrm{m}^{3}$ of treated waters. Since aluminum electrodes are 310 used for the reaction, the electrode dissolution rates were determined to be 0.14 and

$3110.022 \mathrm{~kg} / \mathrm{m} 3$ for the small and the large setup, respectively. Upon completion of the 312 experiment, the clarified water was decanted and analysed for water quality parameters.

\section{$314 \quad 4 \quad$ Results and Discussion}

\section{$315 \quad 4.1$ Characterization}

Wash-water samples were collected from different fruit and vegetable producers

317 and processors in southern Ontario from 2013 - 2015 to better understand and 318 document water quality parameters, and thereby to assess water treatment options. 319 Overall, the characterization and lab scale treatment testing generated a large data set 320 of about 8,000 samples. Facility codes and operating parameters are provided in Table 3211.

Wash-waters from the sampled facilities were grouped into four main categories:

323 tree fruit (apple), leafy greens (spinach), root vegetables (root crop; carrots, potatoes, 324 sweet potatoes, ginseng), and mixed (vegetables grown above ground, root crops, leafy 325 greens and tree fruits). Ranges of water quality parameters encountered in these 326 categories of wash-waters are highlighted in Table 2. Levels of solids, BOD, nutrients 327 (TN\&TP), and pathogens may be predicted from the category of wash-water. Each 328 facility required some or all of the three stages for washing and processing of 329 vegetables and fruits, washing (removal of soil), processing (budding, cutting \& peeling), 330 and packaging (cooling and disinfection). Thus, each facility will be classified according 
331 to the general operations it uses: washing (W) or washing and processing (WP), as 332 indicated in Table 1.

Water quality parameters of tree fruit wash-waters were highly variable as shown

334 in Table 2. The lower values in all categories were due to washing only, while higher 335 values were a result of facilities with juicing lines in addition to washing apples. 336 Similarly, root crops also show high variability in water quality parameters due to 337 facilities both washing and/or processing (cutting/peeling) fruits and vegetables. Leafy 338 greens and mixed wash-waters had the lowest variability in all categories.

Review of Table 2 shows that root crops have high levels of SS, while tree fruit, leafy greens and mixed wash-waters were higher in DS. SS are much easier to treat as 341 they settle out faster in settling ponds/tanks compared to DS. TS are generally higher 342 for root crops due to soils, loose root materials, or wasted products that do not meet 343 quality standards. Float materials were also common in root crop wash-waters. One 344 example is ginseng wash-waters, which contain materials consisting of root hairs. 345 Water flow rates used for washing can also impact level of TS encountered in wash346 waters from different facilities. Low water flow rates (water management) lead to higher 347 level of solids in wash-water, as a result producing a concentrated stream, while higher 348 water flow rates require greater volume of wash-waters to be treated for disposal or 349 reuse. TS levels directly impact other water quality parameters such as COD, BOD, 350 TN, TP and pathogens. 
354 organic matter into the wash-water. High levels of TP exist in wash-waters from tree

355 fruit in comparison to root crops, which were higher in TN levels. The high levels of TP

356 encountered in tree fruit washing is a direct result of 5-day water change cycles for dunk

357 tanks. While, levels of TN and TP were moderate in mixed and quite low in leafy greens

358 wash-waters. The high levels of TP and TN seen in root crops are due to recirculation

359 of wash-water for washing. These practices are utilized in the fruit and vegetable

360 washing industry to reduce water usage for washing and process needs. Fecal

361 indicators such as E.Coli were below detection limit for tree fruit (washing) and leafy

362 greens wash-waters, while root crops, mixed and tree fruit (juicing) had detectable 363 levels.

364 In general, characteristic assessment of fruit and vegetable wash-waters showed 365 that solids are generated by many factors, such as soils and peels. However, DS are 366 contributed by leafy greens and tree fruit washing and processing wash-waters, i.e., for 367 LG1, A1 and A2. High levels of SS are encounter in wash-waters from soil washing 368 only, i.e., for G1, G2, P1, P2, SP1 and SP2, some of the root crops. The values listed in 369 Table 2 show these trends. BOD and COD levels from washing are minimal in 370 comparison to both washing and processing operations. It seems that soil wash-water 371 contributes equally to the generation of TN and TP, unless it is from root vegetables. 372 While washing and processing wash-waters contribute higher loads to TN as compared 373 to TP. 


\subsection{On-site Treatment}

376

377

378

379

380

381

382

Some facilities have on-site treatment systems to handle wash-water while others have access to municipal sewers. On-site treatments systems can be categorized into four types: I) single settling tank/pond, II) three settling tanks/ponds in series, III) four stage sequential reactors (settling, aeration, nutrient removal, settling), and IV) advanced treatment, which composed of membrane bioreactor (MBR), reverse osmosis (RO), and ultraviolet disinfection(UV). Performance of the on-site treatment systems are highlighted in Table 3.

At first glance, it was noticed that some related parameters have different removal rates. This is seen for SS and turbidity, which are not always in agreement, as seen in Table 3, facilities G1-Grasslands, G2, MV1, P1 and P2. This is due to the inherent difference in the measurement method. Turbidity measures the scattering effect particles have on light, while SS is a weighted method of measuring particles in water. The scattering of light is a function of type, size, shape and concentration of particles. Thus, SS and turbidity are not always correlated. Differences in BOD and COD values may be due to COD test's ability to measure oxidation of inorganic chemicals in addition to decomposition of organic matter, the latter being measured by BOD (Patil et al. 2012). Wash-water characteristics can vary in nature, such as in percentage of organic and inorganic matter, dissolved and suspended matter.

Assessment of on-site treatment systems, as highlighted in Table 3, revealed a range of feasible options for disposal and reuse of treated wash-waters. Wash-waters containing high levels of TS and SS utilized settling tanks and ponds to reduce solids. Some producers employed a series of settling tanks to reduce solids as effectively as 
398 possible. The introduction of air into settling ponds (biological treatments) led to a 399 reduction of TP and TN along with BOD and COD. Current water reuse applications

400

401

402

403

404

405

406

407

408

409

410

411

412

413

414

415

416

417 quality testing procedures, CV of $10 \%$ or less was achieved for absorbance,

418 transmittance, turbidity, COD, BOD, and conductivity. Low CV is a result of using

419 instruments with rapid measurements, such as turbidity meter, which give fast and 420 accurate measurements. While TS, SS, TP, TN, and Ammonia were below $18 \%$, which 
421 could be due to methodologic error as they require many steps where human error is 422 also easily introduced. CV for water quality parameters testing indicate high 423 reproducibility and confidence in measurements.

424 Similarly, confidence in bench scale treatments can be assured, as CV for all 425 treatments were $29 \%$ or less. Screening and centrifuge were highly reproducible with a 426 CV of $8 \%$ or less, while CV values for hydrocyclone, settling, and settling with C\&F 427 ranged from 10 to $17 \%$. DAF and EC had CV values of 26 and $29 \%$, respectively, 428 which were to be expected. DAF experiment consisted of many control parameters, 429 such as pressure, water detention rate under pressure, wash-water retention rate in 430 flotation cylinder, and recycle rate. While, EC experiment encountered problem of re431 mixing of solids with clarified waters, which could also have contributed to CV along with 432 inherent human errors. CV analysis highlights no significant errors in the reproducibility 433 of water quality testing and bench scale experiments, thus assuring confidence in study 434 results. system utilized in the education and wastewater sector, the ranges of reduction 437 efficiency corresponding to effectiveness rating were decided upon arbitrarily. These 438 ratings were discussed with colleagues at OMAFRA, who agreed that these ranges 439 would be understood by the user since similar ranges have been used in literature. The 440 ratings are as follows: Poor, $\mathrm{P}$ ( $<40 \%$ removal), Satisfactory, S (40-60\% removal), 441 Good, G (61-75\% removal), Very Good, VG (76-90\% removal), Excellent, E (>90\% 442 removal). 
Ratings for each bench-scale treatment are presented in Tables 4 through 10.

444 For some treatments (screening, hydrocyclone, and settling), fewer water quality 445 parameters were measured due to operational issues in the laboratory. The limited 446 parameters covered essential water quality parameters, such as turbidity, absorbance, 447 and transmittance, which are adequate to assess solids reduction effectively. These 448 are particularly useful when TSS or SS were not available due to their rapid 449 measurement methods, as the case in settling experiment. The primary focus of the 450 study was to assess reduction in solids from different treatments. Removal of solids 451 also impacts other wash-water properties, such as reductions in TN, TP, COD, BOD, 452 pathogens, and other parameters, known as secondary parameters. So, it was 453 important to record the effect on secondary parameters for treatments which have the 454 potential to allow water reuse, such as C\&F, DAF, and electrocoagulation technology.

\subsubsection{Screening} Lab scale testing showed that screening (sieve) treatment was most effective on wash-water from washing that contained heavy levels of sand and large peels (facility 459 SP2 \& G2), followed by other root-vegetables being washed only (facility G1, P2 \& 460 SP1), as seen in Table 4. Results varied between operation types, with process 461 washing vegetables having heavy soils (SP2 \& G2) or utilizing low flow waters (G2) 462 could benefit from the use of screening. Effectiveness in screening varied for washing 463 and peeling facilities; MV1 and C2 showed poor reduction while P3 had good reduction 464 in turbidity. The least effective were A2 and LG1 wash-water as they contained larger 465 proportions of dissolved solids. Overall, screening treatment was effective on wash- 
466 water containing heavy loads of sand, large peel pieces or other larger organics. It was 467 ineffective for wash-water containing dissolved materials (leafy greens and apple 468 washing).

469

470

471

\subsubsection{Hydrocyclone}

Hydrocyclone testing worked well with high levels of solids containing sand, but

472 poorly with other types of wash-waters. As seen in Table 5, facility G2, SP2 and MV1

473 had very good to excellent SS, DS, and TS reductions showing the promise of using

474 hydrocyclone treatment. In addition, facility P2 and P3, which also contain heavy soils

475 showed good reduction in turbidity, this is due to reduction in solids leading to a change

476 in turbidity. It is important to note that hydrocyclone was effective for most root

477 vegetables other than C2, G1 and P1. Facility C2 washes and processes carrots grown

478 in muck soils, which can be difficult to settle out using gravitational forces, as the muck

479 soils contain very high levels of organic matter unlike mineral soils. Facility G1 washed 480 ginseng, which naturally contained float materials from roots and are not suitable for 481 hydrocyclones.

482

483

\subsubsection{Centrifuge}

The centrifuge functions similarly to the hydrocyclone, but the much higher 485 gravitational forces making it easier to remove particles of larger mass. For this 486 reason, it effectively reduced solids in all facilities, as indicated by the high reduction in 487 turbidity and SS, apart from facility A2, which had very high levels of DS, as seen in

488 Table 6. TS reduction ranged from excellent to good ( $E$ to $G$ ) for most facilities that 
489 wash root-vegetables (G1, G2, P1, P2 \& SP2), but satisfactory to poor (S to P) for 490 nearly all washing and processing operations (A1, A2, LG1, C2, MV1 \& P3). BOD and 491 COD reduction varied, but seemed to be least reduced for A2 and LG1. Between TN 492 and TP, TP had higher reduction in comparison to TN. This may suggest that the 493 removed TP was contained within the suspended solids, which are easily removed by 494 centrifugation. Overall treatment impact on water quality parameters varied, but both 495 SS and DS were reduced effectively.

\subsubsection{Settling}

Settling treatment processes allow large solid particles to settle out at the bottom of the pond or tank through gravitational forces. Natural settling is a cost-effective solution to reducing solids from washing and processing wash-waters. Table 7

501 highlights the results from settling experiments composing of "control" jars only, 502 meaning no coagulant were used for these jars, thus highlighting the natural capabilities 503 of wash-waters to settle out particles. Settling was least effective for A2, G2, P2 and 504 P3, which are mostly composed of root-vegetables and processing wash-waters, with 505 high levels of dissolved solids from peels and soils. The dunk tank utilized at facility P2 506 allows for build-up of soils, leading to high levels in TS and SS. Washing and peeling at 507 P3 led to wash-waters with high amounts of fine soils and dispersed organic materials 508 making it challenging for particles to settle.

Facility G2 and P2 require much higher settling times to improve settling 510 efficiency as their wash-waters contained high levels of SS materials. Root vegetable 511 washing and processing wash-waters at facility C2 and MV1, and washing wash-waters 
512 at facility $\mathrm{P} 1, \mathrm{SP} 1, \mathrm{~A} 1$ and LG1 show poor to moderate reduction efficiencies. This is a

513 result of these facilities handling root-vegetables, which generally have heavy loads of

514 soils and peels, making it difficult to reduce all solids with just one treatment step. For

515 the tree fruit and leafy greens, which consist mainly of DS, it is difficult to settle out the 516 solids without the use of coagulants. Overall, wash-water with high levels soils and DS 517 are not effective under settling, such as A2, G2, P2 \& P3.

518

519

520

521

522

523

524

525

526

527

528

529

530

531

532

533

534

535

\subsubsection{Settling with C\&F}

Settling with C\&F was explored to understand improvements in the removal efficiencies of different water quality parameters using chemical aids. All wash-waters for settling with C\&F achieved an excellent to very good reduction for solids, as indicated by turbidity and SS, but dissolved solids were marginally affected as seen in Table 8, which is consistent for coagulation and flocculation. COD reduction ranged from excellent to very good for all wash-waters, except for A2, LG1, and P3. TP had higher reduction compared to TN, expect for LG1 where, both TN and TP were poor. Ammonia and TN were both poor for potato wash-waters.

The applied dosages for jar testing ranged from 5 to $600 \mathrm{mg} / \mathrm{L}$ for Nalco, Chitosan, Polyglu, and Sigma, while metal based precipitation chemicals, such as Alum and $\mathrm{FeCl}$ were much higher at $250-10,000 \mathrm{mg} / \mathrm{L}$. Jar testing results demonstrated that optimal dosages need to be in the range of 5 to $250 \mathrm{mg} / \mathrm{L}$ for Nalco, Chitosan, Polyglu, and Sigma coagulants, as shown in Table 8. These are much lower dosages in comparison to Alum and $\mathrm{FeCl}$ dosages, as they are polymer type coagulants versus conventional metal based coagulants. Polymer coagulants have the advantage of not being dependant on $\mathrm{pH}$ and attracting both inorganic and organic particles. Alum and 
$536 \mathrm{FeCl}$ doses ranged from 250 to $5,000 \mathrm{mg} / \mathrm{L}$, where low $\mathrm{pH}$ wash-waters (approximately

5374 4) were responsible for low dosages leading to $80 \%$ and greater reduction in turbidity

538 (Mundi 2013; Mundi and Zytner 2015). Although detailed jar testing results exist, only a

539 summary was provided to highlight the potential use of different types of coagulants to

540 enhance settling treatment. The summary also demonstrates the variability

541 encountered within wash-water samples and facility, due to several variable operating

542 conditions. Detailed results show variability exists among samples tested under the

543 same coagulant because raw wash-waters have varying properties. These dosages are

544 in line with literature findings on wash-water from root vegetables and leafy greens,

545 which are also very limited (Hafez et al. 2007, Van Haute et al. 2015).

Producers and processors must be aware of optimum coagulant dosages and

547 types (Nalco, Chitosan, Polyglu, Sigma), to optimize treatment system and reduce

548 costs. Compounding the problem are the different wash-waters that are generated 549 throughout the season due to variability in produce coming in or production 550 requirements (processing vs. washing). All four coagulants demonstrated optimum 551 dosages for one type of wash-water or another, highlighting the availability of 552 precipitation chemicals for settling based treatments. Understanding dosage 553 requirements for wash-water allows for a better cost estimate of coagulant use. Further 554 reduction of costs can be achieved by utilizing primary grit chambers. Use of 555 coagulants will help achieve the best treated waters, however dosage and cost must be 556 considered. 
558

559

560

561

562

563

564

565

566

567

568

569

570

571

572

573

574

575

576

577

578

579

580

\subsubsection{Dissolved Air Flotation}

DAF treatment showed promising results as seen in Table 9. DAF was able to reduce COD more effectively than settling and C\&F combined with settling, while also reducing solids and nutrients. This is consistent with DAF be most effective with particles having a light specific gravity. Solids reduction was particularly good for washwaters with high levels of DS (A2, C2, P3, MV1). These are facility with both washing and processing stages. COD seemed to be well reduced for all wash-waters due the addition of oxygen via the air bubbles, except for A2, LG1 and P3, which all have intense processing operations and high levels of dissolved solids. Nutrients were also reduced effectively as TP had a higher reduction rate when compared to TN. The added oxygen provided for better reduction of nutrients when compared to settling with C\&F. Treatment worked well on most wash-waters except for wash-water involving processing (A2, LG1, MV1, P3).

\subsubsection{Electrocoagulation}

EC provides very high levels of treatment as the electrical charge ensures effective COD, BOD, and pathogen reduction, in addition to providing C\&F effect for solids reduction. It is true that EC is effective at removing solids/colloidal matter, however the cause of reduction in pathogen levels (electro-oxidation effect) cannot be confirmed. It is unclear whether the reduction is due to solids or oxidation effect, but a reduction none the less, which is of great interest. Table 10 shows that EC was highly effective on SP2 and G2, wash-waters that had very high levels of soils. More testing is needed with electro-coagulation, as only limited number of samples were tested. Most 
581 wash-waters had a good reduction in all parameters, except for A2, which was due to 582 the heavy loading of solids as seen in the raw wash-waters of facility A2. Facility C1 and 583 LG1 did not show significant reduction in COD and nutrients reductions. Producers that 584 reuse/recycle/recirculate wash-water (A2, G1, C2 and P1) and those using dunk tanks 585 have high dissolved solids (LG1 and SP1), leading to low effectiveness of EC treatment. 586 For improved efficiencies, EC reaction time can be increased or pre-treatment can be 587 introduced. Also, the use of post-treatment such as membrane filtration may be needed 588 to remove dissolved constituents.

\subsection{Treatment Decision Matrices}

The goal of this study was to understand the impact of various treatments on wash-waters from different fruit and vegetable types (root vegetables, leafy greens and fruit) and operation types (washing or washing and processing). Additionally, water reuse potential was addressed as it is important to minimize overall water demand when washing and processing vegetables and fruits. Thus, four decision tables to represent the reduction in solids, COD, TN \& TP, and E.Coli were developed to highlight the

597 effectiveness of each treatment on wash-waters and operation types. Tables 11, 12, 13 598 and 14 are the decision tables that present the treatment effectiveness of various 599 bench-scale treatments on wash-waters presented in this study, according to the 600 operation type (washing - W or washing and processing - WP).

Treatment effectiveness for solids reduction is highlighted in Table 11 . It is

602 important to remove solids from wash-waters whether the end goal is reuse or disposal.

603 The recirculation of wash-waters leads to a buildup of solids, resulting in higher 
604 amounts of pathogens as well as a higher oxygen demand, among other things (Selma 605 et al. 2008a, 2008b; Van Haute et al. 2013, 2015). Thus, it is vital to decrease solids 606 that can be easily reduced via screening and hydrocyclone given the simplicity and cost 607 effectiveness of these treatments.

Natural settling processes can be quite effective under optimal conditions, but the 609 volumes of water used in the fruit and vegetable industry are large, leading to short 610 residence times. Bench-scale settling showed good to poor performances, highlighting 611 the need for optimizing the settling processes. Thus, C\&F with settling was the most 612 effective, given the use of chemical aid. C\&F with settling was the most effective 613 method for rapid treatment and wash-water reuse, followed by EC, DAF, Centrifuge, 614 Settling (natural), $\mathrm{HC}$, and Screening, in that order. Table 12 highlights COD reduction, signifying which treatments can provide the 616 most effective reduction in oxygen demand. EC treatment was the most effective due to 617 electro-oxidation capability, followed by C\&F, DAF and Centrifuge. High COD values 618 combined with high dissolved solids levels, as encountered at facility LG1 and A2, show 619 poor improvements with all bench-scale treatments and produce (apple WP, leafy 620 greens WP, \& potato WP). This makes it challenging to reduce COD effectively 621 regardless of treatment technology employed. Biological treatments utilizing aeration or 622 advanced MBR processes combined with membrane filtration may be the only option 623 wash-waters having elevated COD values like LG1 and A2.

Table 13 presents results for TN and TP reductions. In general, TP was reduced 625 more effectively in comparison to TN using C\&F with settling and DAF (both used 626 chemical coagulants). In contrast, TN and TP were reduced proportionally using 
627 centrifuge treatment. It was evident from Table 13 that mixed vegetable, leafy greens, 628 and apple wash-waters had low reductions in TN compared to TP. In conclusion, both 629 C\&F with settling and DAF are a viable method to reduce TN and TP in wash-waters, 630 due to use of chemicals. Table 14, highlights pathogen reduction, which was 631 surprisingly high yet plausible since most bench-scale treatments could reduce high 632 levels of SS. As SS have the potential to trap and hide a significant number of 633 pathogens.

634 Developing the decision matrices provided in Tables 11 to 14 is considered Phase 6351 of the study as the matrices provide a simple way of approximating which treatment 636 technology should be selected based on the produce and type of wash-water 637 generated. Based on the success of Phase 1, the work continues under Phase 2 of the 638 study which involves creating a statistical model that predicts the most effective 639 treatment option for a particular wash-water type and given specific inputs, such as 640 water quality parameters and operation types. The statistical model will promote more 641 evidence-based decisions surrounding the selection of a feasible treatment system. 642 The results of Phase 2 will lead then into Phase 3 of the study which uses neural 643 network analysis to develop a predictive model for wash-water treatment options.

6455 Summary

Wash-waters generated in the agri-food sector in the processing of fruit and 647 vegetable produce are diverse in water quality parameters as they vary not only across 648 different fruits and vegetables (sector and industry) but also within a particular produce 649 (product) and operation type (facility). The wash-water generated has high variability in 
650 water quality parameters, such as solids, COD, BOD, TN, TP, and pathogens. This

651 variability makes it challenging to implement a standard treatment option. As a result,

652 the fruit and vegetable industry utilizes many treatment options to dispose or reuse 653 wash-waters, ranging from simple settling ponds/tanks to MBR systems. Drinking water 654 standards for water recycling are also met by augmenting (dilution) fresh water with 655 treated wash-waters.

The completed research generated many data points from the sampling of various 657 producer facilities for a variety of fruit and vegetable produce. The sampled wash-water 658 was tested in various bench-scale treatments to determine how effective these 659 treatments were in removing standard water quality concerns like solids, nutrients and 660 organic matter. Analyzing the data allowed the development of treatment decision 661 matrices, which can help producers select the ideal treatment technology for their 662 produce; initially to implement pilot scale, followed by full scale wash-water treatment. 663 The treatment decision matrices also showed the potential for water reuse given the 664 high level of solids and related water quality parameters reduction by some treatments, 665 i.e., C\&F with settling and electrocoagulation. The decision matrices along with 666 compiled information on wash-water characterization and on-site treatments provide 667 growers, government, and consultants with information on determining treatment 668 options that were not previously available or studied in literature.

669

6706 Acknowledgements

671 The authors are thankful for funding provided by OMAFRA. Special thanks to 672 OMAFRA specialists Deanna Nemeth, Rebecca Shortt, and Tim Brook who were vital in 
673 providing sampling partners, technical assistance, and review of this paper; the many 674 vegetable and fruit organizations, cooperators, producers, and processors who 675 participated in the study. The authors like to extend their appreciations to the many 676 coop and summer students for their hard work, without them the large data sets would 677 be impossible; Deanne Durward, Ryan Good, Shreya Ghose, Laurissa Christie, Lindsay 678 Johnston and Duncan Hartwick.

679 


\section{References}

681

682

683

684

685

686

687

688

689

690

691

692

693

694

695

696

697

698

699

700

701

702

703

704

705

706

707

708

709

710

711

712

713

714

715

716

717

718

Alarcón-Flores, M. I., Romero-González, R., Martínez Vidal, J. L., Egea González, F. J. \& Garrido Frenich, A. 2014. Monitoring of phytochemicals in fresh and fresh-cut vegetables: a comparison. Food Chemistry, 142, 392-9. http://doi.org/10.1016/j.foodchem.2013.07.065.

Ahmad, R., Begum, S., Hoek, E. M. V, Karanfil, T., Genceli, E. A., Yadav, A., Trivedi, P. \& Zhang, C. C. 2004. Physico-Chemical Processes. Water Environment Research, 76(6), 823-1002.

Anlauf, H. 2007. Recent developments in centrifuge technology. Separation and Purification Technology, 58(2), 242-246. http://doi.org/10.1016/j.seppur.2007.05.012.

Bain, J. \& Morgan, D. 1983. Laboratory Separation of Clays by Hydrocyclone. Clay Minerals, 33(47).

Bhupathiraju, S. N. \& Tucker, K. L. 2011. Coronary heart disease prevention: nutrients, foods, and dietary patterns. Clinica Chimica Acta; International Journal of Clinical Chemistry, 412(17-18), 1493-514. http://doi.org/10.1016/j.cca.2011.04.038.

Casani, S., Rouhany, M. \& Knochel, S. 2005. A discussion paper on challenges and limitations to water reuse and hygiene in the food industry. Water Research, 39(6), 1134-1146. http://doi.org/10.1016/j.watres.2004.12.015.

Chopra, A. 2011. Overview of Electrolytic treatment: An alternative technology for purification of wastewater. Archives of Applied Science Research, 3(5), 191-206.

Eriksson, E., Auffarth, K., Henze, M., Ledin, A. 2002. Characteristics of grey wastewater. Urban Water, 4, 85-104. doi:10.1016/S1462-0758(01)00064-4.

Drogui, P., Asselin, M., Brar, S. K., Benmoussa, H., \& Blais, J.-F. 2008. Electrochemical removal of pollutants from agro-industry wastewaters. Separation and Purification Technology, 61(3), 301-310. http://doi.org/10.1016/j.seppur.2007.10.013.

Gregory, R., \& Edzwald, J. K. 2011. Sedimentation and Flotation Chapter 9, in Water Quality \& Treatment, by James Edzwald, American Water Works Association.

Hafez, A., Khedr, M. \& Gadallah, H. 2007. Wastewater treatment and water reuse of food processing industries. part II: Techno-economic study of a membrane separation technique. Desalination, 214(1-3), 261-272. http://doi.org/10.1016/j.desal.2006.11.010

Han, M.-Y. \& Kim, W.-T. 2000. Comparison of Sedimentation and Dissolved air floatation modelling for cryptosporidium removal. Korean Society of Environmental Engineers, 5(3), 151-156.

Hwang, K.-J., Hwang, Y.-W. \& Yoshida, H. 2012. Design of novel hydrocyclone for improving fine particle separation using computational fluid dynamics. Chemical Engineering Science, 85, 62-68. http://doi.org/10.1016/j.ces.2011.12.046

Kabdaşli, I., Arslan-Alaton, I., Ölmez-Hancı, T. \& Tünay, O. 2012. Electrocoagulation 
758

759

applications for industrial wastewaters: a critical review. Environmental Technology Reviews, 1(1), 2-45. http://doi.org/10.1080/21622515.2012.715390

Kato, K., Inoue, T., Letsugu, H., Koba, T., Sasaki, H., Miyaji, N., Kitagawa, K., Sharma, P.K. \& Nagasawa, T. 2013. Performance of six multi-stage hybrid wetland systems for treating high-content wastewater in the cold climate of Hokkaido, Japan. Ecological Engineering, 51, 256-263. http://doi.org/10.1016/j.ecoleng.2012.12.002.

Kern, J., Reimann, W. \& Schlüter, O. 2006. Treatment of recycled carrot washing water. Environmental Technology, 27(4), 459-466.

Khiadani, M., Kolivand, R., Ahooghalandari, M. \& Mohajer, M. 2014. Removal of turbidity from water by dissolved air flotation and conventional sedimentation systems using poly aluminum chloride as coagulant. Desalination and Water Treatment, 52(4-6), 985-989. http://doi.org/10.1080/19443994.2013.826339.

Klaiber, R. G., Baur, S., Wolf, G., Hammes, W. P. \& Carle, R. 2005. Quality of minimally processed carrots as affected by warm water washing and chlorination. Innovative Food Science \& Emerging Technologies, 6(3), 351-362. http://doi.org/10.1016/j.ifset.2005.03.002.

Lee, S.L. 2007. Performance Study on Dissolved Air Flotation (DAF) Unit and Process Performance Improvement Study in the Physico-Chemical Treatment of Wastewater, M.Sc. Thesis, University of Technology, Malaysia.

Lehto, M., Sipilä, I., Alakukku, L. \& Kymäläinen, H. 2014. Water consumption and wastewaters in fresh-cut vegetable production, (March), 246-256.

Lehto, M., Sipilä, I., Sorvala, S., Hellstedt, M., Kymäläinen, H. R. \& Sjöberg, A.M. 2009. Evaluation of on-farm biological treatment processes for wastewaters from vegetable peeling. Environmental Technology, 30(1), 3-10. http://doi.org/10.1080/09593330802417019

Ljunggren, M. 2006. Micro screening in wastewater treatment - an overview. Vatten, 62, $171-177$.

Mansour-Geoffrion, M., Dold, P. L., Lamarre, D., Gadbois, A., Déléris, S. \& Comeau, Y. 2010. Characterizing hydrocyclone performance for grit removal from wastewater treatment activated sludge plants. Minerals Engineering, 23(4), 359-364. http://doi.org/10.1016/j.mineng.2009.08.001

Miranda, R., Nicu, R., Latour, I., Lupei, M., Bobu, E. \& Blanco, A. 2013. Efficiency of chitosans for the treatment of papermaking process water by dissolved air flotation. Chemical Engineering Journal, 231, 304-313. http://doi.org/10.1016/j.cej.2013.07.033.

Mundi, G. 2013. Assessment of Effective Solids Removal Technologies to Determine Potential for Vegetable Washwater Reuse. M.A.Sc. Thesis, University of Guelph. Retrieved from https://atrium.lib.uoguelph.ca/xmlui/bitstream/handle/10214/7737/Mundi_ Gurvinder_201312_Msc.pdf?sequence=3\&isAllowed=y

Mundi, G. S. \& Zytner, R. G. 2015. Effective Solid Removal Technologies for Wash- 
Water Treatment to Allow Water Reuse in the Fresh-Cut Fruit and Vegetable Industry. Journal of Agricultural Science and Technology A ,5, 396-407. doi: 10.17265/2161-6256/2015.06.003.

Norton, V.., \& Wilkie, W. 2004. Clarifying Centrifuge Operation and Selection. Chemical Engineering Progress, 100(8), 34.

Ölmez, H. \& Kretzschmar, U. 2009. Potential alternative disinfection methods for organic fresh-cut industry for minimizing water consumption and environmental impact. LWT - Food Science and Technology, 42(3), 686-693. http://doi.org/10.1016/j.lwt.2008.08.001

Park, N. D., Thring, R. W., Garton, R. P., Rutherford, M. P. \& Helle, S. S. 2011. Increased biogas production in a wastewater treatment plant by anaerobic codigestion of fruit and vegetable waste and sewer sludge - A full scale study. Water Science and Technology, 64(9), 1851-1856.

Patil, P. N., Sawant, D. V., \& Deshmukh, R. N. 2012. Physico-chemical parameters for testing of water-A review. International Journal of Environmental Sciences, 3(3), 1194.

Qasim, W. \& Mane, A.V. 2013. Characterization and treatment of selected food industrial effluents by coagulation and adsorption techniques. Water Resources and Industry, 4, 1-12. http://doi.org/10.1016/j.wri.2013.09.005

Renault, F., Sancey, B., Badot, P.-M. \& Crini, G. 2009. Chitosan for coagulation/flocculation processes - An eco-friendly approach. European Polymer Journal, 45(5), 1337-1348. http://doi.org/10.1016/j.eurpolymj.2008.12.027.

Rice, E., Baird, R., Eaton, A., \& Clesceri, L. 2012. Standard Methods for the Examination of Water and Wastewater, 22nd Edition. American Public Health Association, American Water Works Association, Water Environment Federation. p. 1496. ISBN: 9780875530130.

Sahu, O. P. \& Chaudhari, P. K. 2013. Review on Chemical treatment of Industrial Waste Water Review on Chemical treatment. Journal of Applied Science Environmental Management, 17(2), 241-257. http://doi.org/http://dx.doi.org/10.4314/jasem.v17i2.8

Salomonsson, H., Jacxsens, L., Perseyn, J. \& De Meulenaer, B. 2014. Risk profiling of wash waters in vegetable processing industry towards possible allergen carry-over. Food Research International, 55, 190-196. http://doi.org/10.1016/j.foodres.2013.10.045

Selma, M. V., Allende, A., Lopez-Galvez, F., Conesa, M. A. \& Gil, M. I. 2008a. Disinfection potential of ozone, ultraviolet- $C$ and their combination in wash water for the fresh-cut vegetable industry. Food Microbiology, 25, 809e814.

Selma, M. V., Allende, A., Lopez-Galvez, F., Conesa, M. A. \& Gil, M. I. 2008b. Heterogeneous photocatalytic disinfection of wash waters from the fresh-cut vegetable industry. Journal of Food Protection, 71, 286-292.

Shortt, R. \& Nemeth, D. 2013-2016. On-going personal communication, Ontario Ministry of Agriculture, Food and Rural Affairs. 
Singh, N. \& Eckhoff, S. R. 1995. Hydrocyclone Procedure for Starch-Protein Separation in Laboratory Wet Milling. Cereal Chemistry, 72, 344-348. American Association of Cereal Chemists, Inc. Retrieved on March 15, 2017 from http://www.aaccnet.org/publications/cc/backissues/1995/Documents/cc1995a72.ht $\mathrm{ml}$.

Soccol, O. J. \& Botrel, T.A. 2004. Hydrocyclone for pre-filtering of irrigation water. Scientia Agricola, 61(2), 134-140. http://doi.org/10.1590/S010390162004000200002.

Soerjomataram, I., Oomen, D., Lemmens, V., Oenema, A., Benetou, V., Trichopoulou, A., Coebergh, J.W., Barendregt, J. \& de Vries, E. 2010. Increased consumption of fruit and vegetables and future cancer incidence in selected European countries. European Journal of Cancer (Oxford, England: 1990), 46(14), 2563-80. http://doi.org/10.1016/j.ejca.2010.07.026

Son, J. H., Hong, M., Yoo, H. C., Kim, Y. I., Kim, H. Do. \& Kim, J. T. 2016. A multihydrocyclone water pretreatment system to reduce suspended solids and the chemical oxygen demand. Desalination and Water Treatment, 57(7), 2996-3001. http://doi.org/10.1080/19443994.2014.987827.

Statistics Canada. (2016). Fruit and vegetable production, 2015. The Daily. Retrieved on November 21, 2016 from http://www.statcan.gc.ca/dailyquotidien/160203/dq160203a-eng.pdf.

Stefler, D., Pikhart, H., Kubinova, R., Pajak, A., Stepaniak, U., Malyutina, S., Simonova, G., Peasey, A., Marmot, M.G. \& Bobak, M. 2016. Fruit and vegetable consumption and mortality in Eastern Europe: Longitudinal results from the Health, Alcohol and Psychosocial Factors in Eastern Europe study. European Journal of Preventive Cardiology, 23(5), 493-501. http://doi.org/10.1177/2047487315582320.

Teixeira, M. R. \& Rosa, M. J. 2007. Comparing dissolved air flotation and conventional sedimentation to remove cyanobacterial cells of Microcystis aeruginosa. Part II. The effect of water background organics. Separation and Purification Technology, 53(1), 126-134. http://doi.org/10.1016/j.seppur.2006.07.001

USEPA. 1999. Enhanced Coagulation and Enhanced Precipitative Softening Guidance Manual.

USEPA. 2000. Biosolids Technology Fact Sheet Centrifuge Thickening and Dewatering.

Valta, K., Kosanovic, T., Malamis, D., Moustakas, K. \& Loizidou, M. 2015. Overview of water usage and wastewater management in the food and beverage industry. Desalination and Water Treatment, 53(12), 3335-3347. http://doi.org/10.1080/19443994.2014.934100

Van Haute, S., Uyttendaele, M. \& Sampers, I. 2015. Coagulation of turbidity and organic matter from leafy-vegetable wash-water using chitosan to improve water disinfectant stability. LWT - Food Science and Technology, 64(1), 337-343. http://doi.org/10.1016/j.lwt.2015.05.063

Verberne, P. 1977. A New Hydrocyclone Process for the Production of Potato Starch with Lowest Fresh Water Consumption. Starch/Stärke, 29: 303-307. 
843

844

845

846

847

848

849

850

851

852 doi:10.1002/star.19770290906

Warriner, K, Barrera, M. J. \& Blenkinsop, R. 2012. The effect of different processing parameters on the efficacy of commercial post-harvest washing of minimally processed spinach and shredded lettuce. Food Control, 25:745-751

WCM Consulting Inc. 2004. Eastern Ontario Food-processing Sector Competitiveness Study.

Yang, Q., Li, Z. M., Lv, W. J. \& Wang, H. L. 2013. On the laboratory and field studies of removing fine particles suspended in wastewater using mini-hydrocyclone. Separation and Purification Technology, 110, 93-100. http://doi.org/10.1016/j.seppur.2013.03.025. 


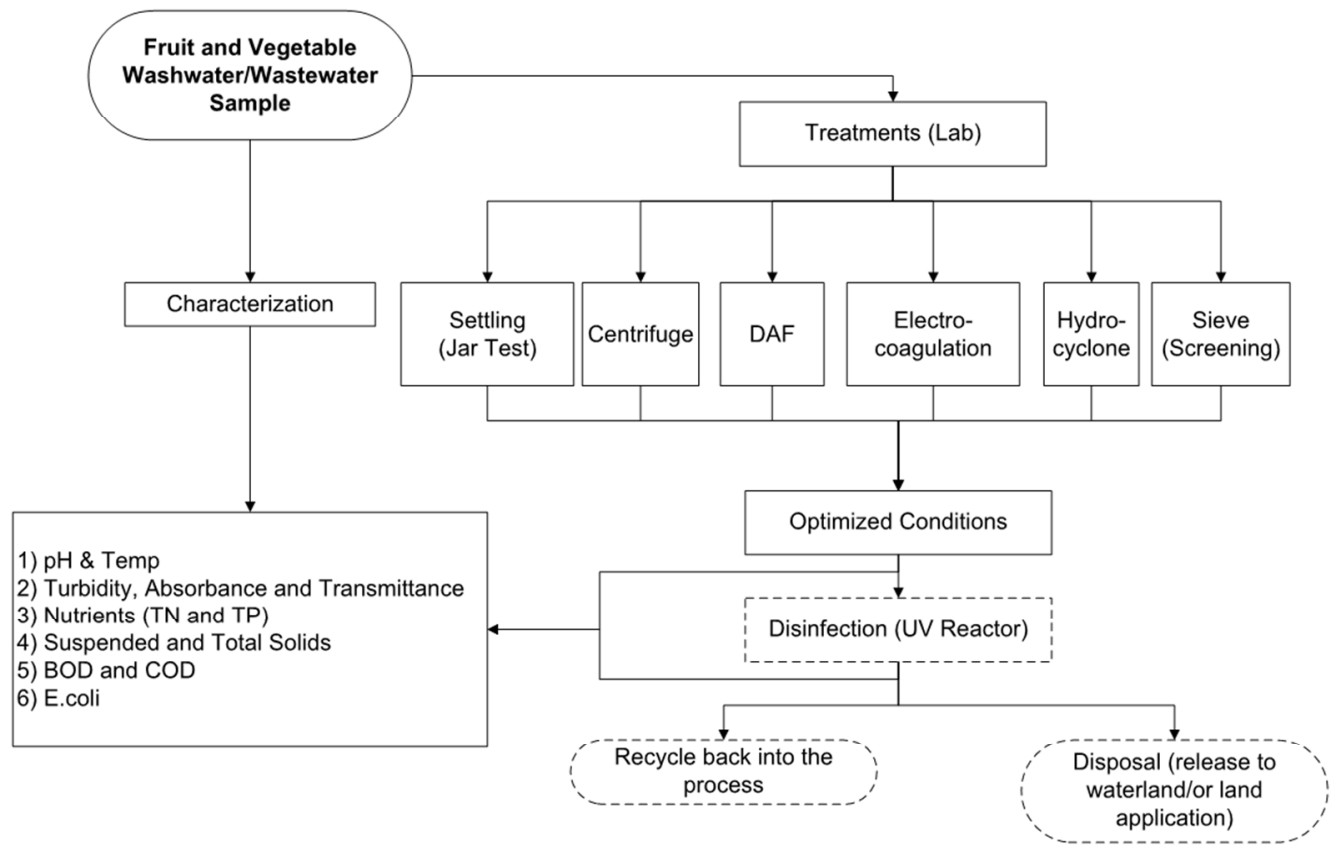

Figure 1: Process Flow Diagram of Wash-water Bench-scale Treatment Testing 
Table 1: Vegetable and Fruit Washing and Processors Wash-water Information.

\begin{tabular}{|c|c|c|c|c|c|}
\hline FACILITY & $\begin{array}{l}\text { TYPE OF } \\
\text { PRODUCE }\end{array}$ & $\begin{array}{l}\text { OPERATION } \\
\text { TYPES* }\end{array}$ & $\begin{array}{c}\text { WATER USAGE } \\
\text { AND OPERATION } \\
\text { LENGTH }\end{array}$ & $\begin{array}{l}\text { TREATMENT } \\
\text { TYPE AND } \\
\text { VOLUME }\left(\mathrm{m}^{3}\right)\end{array}$ & $\begin{array}{l}\text { SAMPLES (\# } \\
\text { COLLECTED) }\end{array}$ \\
\hline A1 & Apple & W & NA & Sand Filtration & $\begin{array}{l}{ }^{* *} \mathrm{~A} 1 \mathrm{~F} 1(1), \\
\text { A1F2 (1), and } \\
\text { A1F3 (1); N=3 }\end{array}$ \\
\hline A2 & Apple & WP (Juicing) & $10 \mathrm{~m}^{3} / \mathrm{hr}$; All year & $\begin{array}{l}\text { Biological MBR with } \\
\text { RO and UV }\end{array}$ & $\begin{array}{l}\text { Pre and post } \\
\text { treatment; } \\
\mathrm{N}=4\end{array}$ \\
\hline C1 & Carrot & WP (Peeling) & $14 \mathrm{~m}^{3} / \mathrm{hr}$; Half year & Settling Pond & $\begin{array}{l}\text { Multiple } \\
\text { samples along } \\
\text { processing line, } \\
\text { pre and post } \\
\text { treatment; } \mathrm{N}= \\
16\end{array}$ \\
\hline C2 & Carrot & WP (Peeling) & $\begin{array}{c}114 \mathrm{~m}^{3} / \mathrm{hr} ; \text { Half } \\
\text { year }\end{array}$ & $\begin{array}{l}\text { Settling Tank }-543 \\
\mathrm{~m}^{3}\end{array}$ & $\begin{array}{l}\text { Pre and post } \\
\text { treatment; } \\
\quad \mathrm{N}=6\end{array}$ \\
\hline G1 & Ginseng & W & $\begin{array}{c}15 \mathrm{~m}^{3} / \mathrm{hr} \text { for } \\
10 \mathrm{hr} / \mathrm{day} \text { and } 1 \\
\text { week/yr }\end{array}$ & $\underset{\mathrm{m}^{3}}{\text { Settling Tank }}-6.5$ & $\begin{array}{l}\text { Pre and post } \\
\text { treatment; } \\
\qquad \mathrm{N}=4\end{array}$ \\
\hline G2 & Ginseng & W & $\begin{array}{c}1.4 \mathrm{~m}^{3} / \mathrm{hr} \text { for } \\
9 \mathrm{hr} / \text { day and } 12 \\
\text { days/yr }\end{array}$ & $\underset{\mathrm{m}^{3}}{\text { Settling Tank }} 1.8$ & $\begin{array}{l}\text { Pre and post } \\
\text { treatment; } \\
\qquad \mathrm{N}=4\end{array}$ \\
\hline LG1 & Spinach & W & NA; All year & $\begin{array}{c}\text { Effluent to } \\
\text { Municipal Sewer }\end{array}$ & $\begin{array}{l}\text { Raw wash- } \\
\text { waters; } N=3\end{array}$ \\
\hline MV1 & Root vegetables & WP & NA & $\begin{array}{l}\text { Series of } 3 \text { settling } \\
\text { tanks/ponds }\end{array}$ & $\begin{array}{l}\text { Raw wash- } \\
\text { waters; } N=6\end{array}$ \\
\hline MV2 & $\begin{array}{l}\text { Vegetable grown } \\
\text { above ground, root } \\
\text { vegetables, leafy } \\
\text { greens and apple }\end{array}$ & WP (Peeling) & $15 \mathrm{~m}^{3} / \mathrm{hr}$; All year & $\begin{array}{l}\text { Sieve, settling tank, } \\
\text { followed by effluent } \\
\text { release to } \\
\text { Municipal Sewer }\end{array}$ & $\begin{array}{l}\text { Raw wash- } \\
\text { waters; } N=12\end{array}$ \\
\hline P1 & Potato & W & $1.7 \mathrm{~m}^{3} / \mathrm{hr}$; Half year & $\begin{array}{l}4 \text { Cell SBR - Each } \\
\text { cell } 100 \mathrm{~m}^{3}\end{array}$ & $\begin{array}{c}\text { Pre and post } \\
\text { treatment; } N=6\end{array}$ \\
\hline P2 & Potato & W & $2.8 \mathrm{~m}^{3} / \mathrm{hr} ; \mathrm{NA}$ & $\begin{array}{c}3 \text { Settling ponds } \\
\text { (settling-aeration- } \\
\text { settling) - Each } \\
\text { about } 250 \mathrm{~m}^{3} \\
\text { followed by } 2 \\
\text { wetlands - Each } 80 \\
\mathrm{~m}^{3}\end{array}$ & $\begin{array}{l}\text { Pre and post } \\
\text { treatment; } \\
\quad \mathrm{N}=5\end{array}$ \\
\hline P3 & Potato & WP (Peeling) & NA & $\begin{array}{l}3 \text { Settling tanks - } \\
\text { (1) } 1.5 \mathrm{~m}^{3}(2) 10 \mathrm{~m}^{3} \\
\text { (3) } 1 \mathrm{~m}^{3}\end{array}$ & $\begin{array}{l}\text { Pre and post } \\
\text { treatment; } \\
\qquad \mathrm{N}=6\end{array}$ \\
\hline SP1 & Sweet Potato & W & NA & $\begin{array}{l}\text { Settling tank - } 6.7 \\
\mathrm{~m}^{3} \text { followed by } \\
\text { settling pond }-34 \\
\mathrm{~m}^{3}\end{array}$ & $\begin{array}{l}\text { Pre and post } \\
\text { treatment; } N=6\end{array}$ \\
\hline SP2 & Sweet Potato & W & NA & NA & $\begin{array}{l}\text { Pre and post } \\
\text { treatment; } \mathrm{N}=2\end{array}$ \\
\hline
\end{tabular}


Table 2: Range of Raw Wash-water Quality Parameters of Tree Fruit, Root Crops, Leafy Greens and Mixed Categories between washing (W) versus washing and processing (WP)

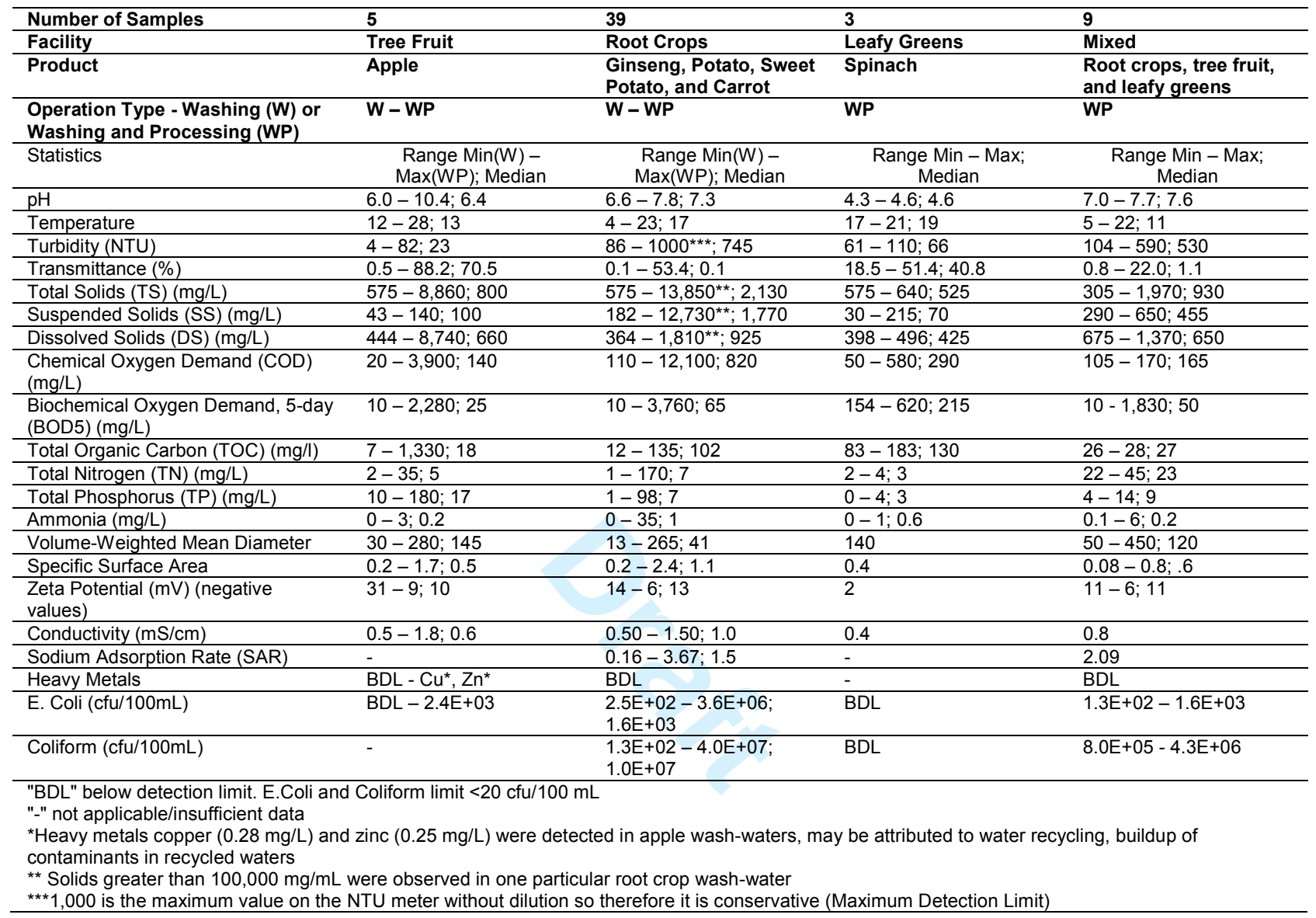


Table 3: Performance of On-site Wash-water Treatment Systems.

\begin{tabular}{|c|c|c|c|c|c|c|c|c|c|c|}
\hline Facility & A2 & C2 & G1 & & G2 & MV1 & P1 & P2 & P3 & SP1 \\
\hline Treatment Type & IV & I & I & $\begin{array}{l}\text { Grasslan } \\
\text { ds }\end{array}$ & 1 & II & III & III & II & I \\
\hline Number of Samples & 2 & 3 & 3 & 3 & 2 & 3 & 3 & 2 & 2 & 2 \\
\hline Turbidity & $\mathrm{E}$ & $\mathrm{P}$ & $\mathrm{P}$ & $E$ & $\mathrm{P}$ & VG & VG & $\mathrm{E}$ & $\mathrm{P}$ & $\mathrm{P}$ \\
\hline Transmittance & $\mathrm{E}$ & $P$ & $\mathrm{~S}$ & $\mathrm{P}$ & $\mathrm{P}$ & $\mathrm{P}$ & $\mathrm{P}$ & $\mathrm{P}$ & $\mathrm{P}$ & $\mathrm{P}$ \\
\hline TS & $\mathrm{E}$ & $\mathrm{P}$ & $\mathrm{P}$ & G & $\mathrm{S}$ & VG & $\mathrm{E}$ & $\mathrm{E}$ & $\mathrm{P}$ & $\mathrm{s}$ \\
\hline SS & $\mathrm{E}$ & $P$ & $P$ & $\mathrm{P}$ & G & $\mathrm{P}$ & $\mathrm{P}$ & $\mathrm{P}$ & $\mathrm{P}$ & $\mathrm{P}$ \\
\hline TDS & $\mathrm{E}$ & $\mathrm{P}$ & $\mathrm{P}$ & $G$ & $\mathrm{E}$ & $\mathrm{S}$ & VG & $\mathrm{s}$ & VG & $\mathrm{S}$ \\
\hline COD & $\mathrm{E}$ & $\mathrm{P}$ & $\mathrm{P}$ & $\mathrm{P}$ & - & $\mathrm{P}$ & $\mathrm{P}$ & $\mathrm{P}$ & $\mathrm{P}$ & - \\
\hline BOD5 & $\mathrm{E}$ & $P$ & $P$ & $E$ & VG & VG & $\mathrm{E}$ & $\mathrm{E}$ & VG & $\mathrm{P}$ \\
\hline TOC & $\mathrm{E}$ & $P$ & $\mathrm{P}$ & $P$ & $\mathrm{P}$ & $\mathrm{P}$ & $\mathrm{P}$ & $\mathrm{P}$ & $\mathrm{P}$ & - \\
\hline TN & $E$ & $\mathrm{P}$ & $\mathrm{P}$ & $\mathrm{P}$ & $\mathrm{E}$ & $\mathrm{P}$ & $\mathrm{P}$ & $\mathrm{P}$ & $\mathrm{P}$ & G \\
\hline TP & $\mathrm{E}$ & $P$ & $\mathrm{P}$ & $\mathrm{P}$ & - & $\mathrm{P}$ & $\mathrm{S}$ & $\mathrm{P}$ & $\mathrm{S}$ & - \\
\hline Ammonia & $\mathrm{E}$ & $P$ & $\mathrm{P}$ & $\mathrm{G}$ & $\mathrm{P}$ & $\mathrm{S}$ & $\mathrm{E}$ & VG & VG & $\mathrm{P}$ \\
\hline Conductivity & $\mathrm{E}$ & $P$ & $\mathrm{P}$ & $\mathrm{P}$ & - & - & $\mathrm{P}$ & VG & $\mathrm{P}$ & - \\
\hline E. Coli (log) & $E$ & $P$ & G & $E$ & $\mathrm{P}$ & $G$ & $\mathrm{E}$ & $\mathrm{P}$ & $\mathrm{G}$ & G \\
\hline Coliform (log) & - & $P$ & $\mathrm{P}$ & - & $P$ & $P$ & S & - & - & $\mathrm{P}$ \\
\hline
\end{tabular}

Table 4: Screening (Sieve) Treatment Results of 10 Different Facilities Washing and Processing Vegetables and Fruits.

\begin{tabular}{|l|l|l|l|l|l|l|l|l|l|l|}
\hline Facility & A2 & C2 & G1 & G2 & LG1 & MV1 & P2 & P3 & SP1 & SP2 \\
\hline Operation Type & WP & WP & W & W & W & WP & W & WP & W & W \\
\hline Tested Samples & $\mathbf{1 - 2}$ & $\mathbf{3}$ & $\mathbf{2 - 3}$ & $\mathbf{3}$ & $\mathbf{1 - 3}$ & $\mathbf{2 - 3}$ & $\mathbf{2 - 3}$ & $\mathbf{1 - 3}$ & $\mathbf{2}$ & $\mathbf{1}$ \\
\hline Turbidity & P & P & P & - & P & P & G & G & P & P \\
\hline Transmittance & P & S & S & P & P & P & S & P & P & G \\
\hline TS & P & - & P & VG & - & P & P & - & S & VG \\
\hline SS & P & P & P & S & S & P & P & P & P & VG \\
\hline DS & P & - & S & - & - & P & E & - & VG & S \\
\hline $\begin{array}{l}\text { P (र40\% removal), S (40-60\% removal), G (61-75\% reval), VG (76-90\% removal), E (>90\% removal), "-" not } \\
\text { applicable/insufficient data }\end{array}$ \\
\hline
\end{tabular}

Table 5: Hydrocyclone Treatment Results of 12 Different Facilities Washing and Processing Vegetables and Fruits.

\begin{tabular}{|l|l|l|l|l|l|l|l|l|l|l|l|l|}
\hline Facility & A2F1 & A2 & C2 & G1 & G2 & LG1 & MV1 & P1 & P2 & P3 & SP1 & SP2 \\
\hline $\begin{array}{l}\text { Operation } \\
\text { Type }\end{array}$ & W & WP & WP & W & W & WP & W & W & W & WP & W & W \\
\hline $\begin{array}{l}\text { Tested } \\
\text { Samples }\end{array}$ & $\mathbf{1}$ & $\mathbf{1 - 2}$ & $\mathbf{3}$ & $\mathbf{2 - 3}$ & $\mathbf{2}$ & $\mathbf{2 - 3}$ & $\mathbf{2 - 3}$ & $\mathbf{3}$ & $\mathbf{1 - 3}$ & $\mathbf{1 - 3}$ & $\mathbf{2 - 3}$ & $\mathbf{2}$ \\
\hline Turbidity & P & P & P & P & - & P & S & P & G & G & P & P \\
\hline Transmittance & P & P & P & P & - & P & G & P & P & P & P & G \\
\hline TS & - & P & - & P & E & P & S & - & P & S & P & E \\
\hline SS & - & S & - & P & VG & P & VG & - & P & P & P & E \\
\hline DS & - & P & - & P & E & P & P & - & - & P & P & VG \\
\hline $\begin{array}{l}\text { P (<40\% removal), S (40-60\% removal), G (61-75\% removal), VG (76-90\% removal), E (>90\% removal), "-" not } \\
\text { applicable/insufficient data }\end{array}$
\end{tabular}


Table 6: Centrifuge Treatment Results of 14 different wash-waters.

\begin{tabular}{|c|c|c|c|c|c|c|c|c|c|c|c|c|c|c|}
\hline Facility & $\begin{array}{l}\text { A1(F1, } \\
\text { F2, } \\
\text { F3)* }\end{array}$ & A2 & $\mathrm{C} 2$ & G1 & G2 & LG1 & $\begin{array}{l}\text { MV } \\
1\end{array}$ & P1 & P2 & P3 & SP1 & SP2 & C1 & $\begin{array}{l}\text { MV } \\
2\end{array}$ \\
\hline $\begin{array}{l}\text { Operation } \\
\text { Type }\end{array}$ & W & WP & WP & $\mathbf{W}$ & $\mathbf{W}$ & $\mathbf{W}$ & WP & $\mathbf{W}$ & $\mathbf{W}$ & WP & $\mathbf{W}$ & $\mathbf{W}$ & WP & WP \\
\hline $\begin{array}{l}\text { Tested } \\
\text { Samples }\end{array}$ & 1 & $1-2$ & $1-3$ & $1-2$ & 2 & $1-3$ & $1-3$ & $1-3$ & $1-3$ & $1-3$ & $1-3$ & 1 & 16 & 12 \\
\hline Turbidity & $\begin{array}{l}\text { VG, P, } \\
S\end{array}$ & $\mathrm{P}$ & VG & $E$ & $G$ & VG & $E$ & $E$ & VG & $G$ & $E$ & $E$ & $E$ & $G$ \\
\hline Transmittance & $\mathrm{P}$ & $\mathrm{P}$ & $G$ & $\mathrm{~S}$ & $\mathrm{~S}$ & $\mathrm{P}$ & VG & $E$ & $E$ & $\mathrm{~S}$ & VG & $E$ & VG & - \\
\hline TS & $P$ & $P$ & $P$ & $\mathrm{G}$ & $E$ & $S$ & $\mathrm{~S}$ & $G$ & $G$ & $\mathrm{~S}$ & $\mathrm{~S}$ & $E$ & - & - \\
\hline SS & $\begin{array}{l}\text { G, E, } \\
\text { VG }\end{array}$ & $S$ & G & $E$ & $E$ & VG & $E$ & $E$ & VG & $E$ & G & $E$ & $E$ & - \\
\hline DS & $\mathrm{P}$ & VG & $\mathrm{P}$ & $\mathrm{P}$ & $E$ & $\mathrm{P}$ & $\mathrm{P}$ & $\mathrm{P}$ & $\mathrm{P}$ & $\mathrm{P}$ & $\mathrm{S}$ & VG & - & - \\
\hline COD & $\begin{array}{l}\text { VG, P, } \\
P\end{array}$ & $\mathrm{P}$ & G & $E$ & $E$ & $\mathrm{P}$ & G & VG & $G$ & $S$ & $\mathrm{P}$ & $G$ & - & - \\
\hline BOD5 & $\begin{array}{l}\text { G, P, } \\
\text { VG }\end{array}$ & $\mathrm{P}$ & $S$ & VG & $S$ & $\mathrm{P}$ & $\mathrm{S}$ & $S$ & $\mathrm{P}$ & $\mathrm{P}$ & $P$ & - & $\mathrm{P}$ & $\mathrm{P}$ \\
\hline TOC & $\begin{array}{l}\text { VG, P, } \\
S\end{array}$ & $\mathrm{P}$ & $S$ & - & - & - & $\mathrm{S}$ & $\mathrm{P}$ & $\mathrm{P}$ & $\mathrm{P}$ & - & - & - & - \\
\hline $\mathrm{TN}$ & $\mathrm{P}$ & $\mathrm{P}$ & $\mathrm{S}$ & $G$ & VG & $\mathrm{P}$ & $\mathrm{P}$ & $\mathrm{P}$ & $\mathrm{P}$ & $\mathrm{P}$ & $\mathrm{G}$ & $E$ & $\mathrm{~S}$ & - \\
\hline TP & $\mathrm{P}$ & $\mathrm{P}$ & $\mathrm{P}$ & VG & VG & $\mathrm{P}$ & VG & VG & $\mathrm{S}$ & $G$ & $\mathrm{G}$ & $E$ & $\mathrm{P}$ & - \\
\hline Ammonia & $\mathrm{P}$ & $P$ & $G$ & $\mathrm{G}$ & VG & $\mathrm{P}$ & $P$ & $\mathrm{P}$ & $\mathrm{P}$ & $\mathrm{P}$ & VG & VG & $\mathrm{P}$ & - \\
\hline Conductivity & $\mathrm{P}$ & $\mathrm{P}$ & $\mathrm{P}$ & - & - & $\mathrm{P}$ & $\mathrm{P}$ & $\mathrm{P}$ & $\mathrm{P}$ & $\mathrm{P}$ & - & - & - & - \\
\hline E. Coli & BDL & $E$ & - & $E$ & $E$ & BDL & $E$ & - & $\mathrm{P}$ & VG & VG & $\mathrm{P}$ & $E$ & - \\
\hline $\begin{array}{l}\mathrm{P}(<40 \% \text { remova } \\
\text { applicable/insuffi } \\
{ }^{*} \mathrm{~F} 1 \text { - Flume } 1, \mathrm{~F}\end{array}$ & $\begin{array}{l}(40-60 \\
\text { t data }\end{array}$ & 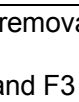 & 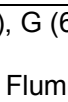 & & & & 2 & & & & & & & \\
\hline
\end{tabular}

Table 7: Settling Without any Chemical Aid, Natural Settling Results of 14 different Wash-waters

\begin{tabular}{|c|c|c|c|c|c|c|c|c|c|c|c|c|c|}
\hline Facility & $\begin{array}{l}\text { A1 (F1, } \\
\text { F2, \& } \\
\text { F3)* }\end{array}$ & A2 & C2 & G1 & G2 & LG1 & $\begin{array}{l}\text { MV } \\
1\end{array}$ & P1 & P2 & P3 & SP1 & SP2 & C1 \\
\hline $\begin{array}{l}\text { Operation } \\
\text { Type }\end{array}$ & $\mathbf{W}$ & WP & WP & $\mathbf{W}$ & $\mathbf{W}$ & $\mathbf{W}$ & WP & $\mathbf{W}$ & $\mathbf{W}$ & WP & $\mathbf{W}$ & $\mathbf{W}$ & WP \\
\hline $\begin{array}{l}\text { Tested } \\
\text { Samples }\end{array}$ & 1 & $1-2$ & $1-3$ & $1-2$ & $1-2$ & $1-3$ & $1-3$ & $1-3$ & $1-3$ & $1-3$ & $1-3$ & 1 & 1 \\
\hline Turbidity & $G, S, P$ & $\mathrm{P}$ & VG & $G$ & $\mathrm{P}$ & $G$ & $\mathrm{G}$ & $\mathrm{P}$ & $\mathrm{P}$ & $\mathrm{P}$ & $\mathrm{S}$ & $G$ & $\mathrm{P}$ \\
\hline Transmittance & $P$ & $P$ & $G$ & $\mathrm{~S}$ & $P$ & $P$ & $\mathrm{G}$ & VG & $P$ & $P$ & $P$ & $E$ & $P$ \\
\hline
\end{tabular}


Table 8: Settling with C\&F Treatment Results of 13 different Facilities.

\begin{tabular}{|c|c|c|c|c|c|c|c|c|c|c|c|c|c|}
\hline Facility & $\begin{array}{l}\text { A1 } \\
\text { (F1,F2,\&F3) }\end{array}$ & A2 & $\mathrm{C2}$ & G1 & G2 & LG1 & MV1 & P1 & P2 & P3 & $\begin{array}{l}\text { SP } \\
1\end{array}$ & $\begin{array}{l}\text { SP } \\
2\end{array}$ & C1 \\
\hline Process Type & $\mathbf{W}$ & WP & WP & $\mathbf{W}$ & $\mathbf{W}$ & $\mathbf{W}$ & WP & $\mathbf{W}$ & $\mathbf{W}$ & WP & $\mathbf{W}$ & $\mathbf{W}$ & WP \\
\hline Tested Samples & $1,1,1$ & $1-2$ & $1-3$ & $1-2$ & 2 & $1-3$ & $1-3$ & $1-3$ & $1-3$ & $1-3$ & $1-3$ & 1 & 5 \\
\hline Turbidity & VG & $E$ & $E$ & $E$ & $\mathrm{E}$ & $E$ & $E$ & $\mathrm{E}$ & $E$ & $E$ & $\mathrm{E}$ & $E$ & VG \\
\hline Transmittance & $\mathrm{P}$ & $E$ & $E$ & $G$ & $E$ & $\mathrm{~S}$ & $E$ & $E$ & $E$ & $E$ & VG & $E$ & - \\
\hline TS & - & - & $\mathrm{S}$ & $\mathrm{S}$ & $E$ & G & $\mathrm{P}$ & VG & VG & $\bar{G}$ & $\mathrm{~S}$ & $E$ & - \\
\hline SS & - & - & $\mathrm{E}$ & $\mathrm{E}$ & $\mathrm{E}$ & $E$ & $E$ & $\mathrm{E}$ & $\mathrm{E}$ & $E$ & VG & $E$ & - \\
\hline TDS & - & - & $\mathrm{P}$ & $\mathrm{P}$ & VG & $\mathrm{G}$ & $\mathrm{P}$ & $\mathrm{S}$ & $\mathrm{P}$ & $\mathrm{P}$ & $\mathrm{S}$ & VG & - \\
\hline COD & - & $\mathrm{P}$ & $E$ & VG & VG & $\mathrm{P}$ & VG & $E$ & VG & $\mathrm{S}$ & $\mathrm{E}$ & $\mathrm{G}$ & - \\
\hline BOD5 & - & - & - & - & $\mathrm{P}$ & $\mathrm{P}$ & $G$ & - & VG & $\mathrm{P}$ & - & $\mathrm{P}$ & - \\
\hline TOC & - & $\mathrm{P}$ & $G$ & - & - & $\mathrm{P}$ & VG & $\mathrm{G}$ & VG & $\mathrm{P}$ & - & - & - \\
\hline TN & - & $\mathrm{P}$ & $\mathrm{G}$ & VG & VG & $\mathrm{P}$ & $\mathrm{P}$ & $\mathrm{S}$ & $\mathrm{S}$ & $\mathrm{P}$ & VG & $\mathrm{E}$ & - \\
\hline TP & - & $E$ & VG & $E$ & $E$ & $\mathrm{P}$ & $E$ & $E$ & VG & $E$ & $E$ & - & - \\
\hline Ammonia & - & VG & - & VG & $G$ & $\mathrm{~S}$ & VG & $\mathrm{P}$ & $\mathrm{P}$ & $\mathrm{P}$ & VG & $G$ & - \\
\hline Conductivity & $\mathrm{P}$ & - & $\mathrm{P}$ & $\mathrm{P}$ & - & - & $\mathrm{P}$ & $\mathrm{P}$ & $\mathrm{P}$ & - & $\mathrm{P}$ & - & - \\
\hline E. Coli & $\mathrm{BDL}$ & - & $E$ & VG & $E$ & $\mathrm{BDL}$ & $E$ & - & $E$ & $E$ & VG & G & - \\
\hline Coagulants & - & $\begin{array}{l}\mathrm{N}, \\
\mathrm{C}\end{array}$ & $\mathrm{N}$ & $\mathrm{N}, \mathrm{P}$ & C & $\mathrm{N}$ & $\mathrm{N}, \mathrm{P}$ & $\mathrm{N}$ & $\mathrm{N}, \mathrm{C}$ & C & $\mathrm{N}$ & $\mathrm{N}$ & $\mathrm{F}, \mathrm{A}$ \\
\hline Dosage (mg/L) & - & $\begin{array}{l}200 \\
50\end{array}$ & $\begin{array}{l}25- \\
100\end{array}$ & $\begin{array}{l}200 \\
25\end{array}$ & 150 & 10 & $\begin{array}{l}25- \\
50 \\
200\end{array}$ & $\begin{array}{l}50- \\
200\end{array}$ & $\begin{array}{l}150- \\
250 \\
25\end{array}$ & $\begin{array}{l}25- \\
150\end{array}$ & $\begin{array}{l}5- \\
200\end{array}$ & 25 & $\begin{array}{l}200 \\
0\end{array}$ \\
\hline \multicolumn{14}{|c|}{$\begin{array}{l}\mathrm{P}(<40 \% \text { removal), S (40-60\% removal), G (61-75\% removal), } \\
\text { applicable/insufficient data } \\
\text { "F1 - Flume 1, F2 - Flume 2, and F3 - Flume } 3 \\
\text { N - Nalco ULTRION } 8187 \text { (Aluminum Chloride Hydroxide), } \\
\text { C - Chitosan (a polysaccharide), } \\
\text { S - Sigma-Aldrich (Poly(diallyldimethylammonium chloride)), } \\
\text { P - Polyglu (Water Treatment Agent PGa21Ca), } \\
\text { A - Aluminum Sulphate - Al2(SO4)3.14H2O, } \\
\text { F - Ferric Chloride - FeCl3.6H2O. }\end{array}$} \\
\hline
\end{tabular}


Table 9: DAF Treatment Results of 13 different Facilities.

\begin{tabular}{|c|c|c|c|c|c|c|c|c|c|c|c|c|c|}
\hline Facility & A2 & $\mathrm{C} 2$ & G1 & G2 & LG1 & MV1 & P1 & P2 & P3 & SP1 & SP2 & C1 & MV2 \\
\hline Process Type & WP & WP & $\mathbf{W}$ & $\mathbf{W}$ & $\mathbf{W}$ & WP & $\mathbf{W}$ & $\mathbf{W}$ & WP & $\mathbf{W}$ & $\mathbf{W}$ & WP & WP \\
\hline Tested Samples & 1 & $1-3$ & $1-2$ & 2 & $2-3$ & $1-3$ & $1-3$ & $1-3$ & $1-3$ & $1-3$ & 1 & 16 & 4 \\
\hline Turbidity & $\mathrm{P}$ & $\mathrm{P}$ & VG & VG & $\mathrm{E}$ & VG & - & $\mathrm{E}$ & VG & $\mathrm{S}$ & $\mathrm{E}$ & $\mathrm{E}$ & $\mathrm{E}$ \\
\hline Transmittance & VG & VG & $\mathrm{S}$ & $E$ & $\mathrm{~S}$ & VG & - & $E$ & VG & G & $E$ & $E$ & $E$ \\
\hline TS & - & $\mathrm{S}$ & $\mathrm{S}$ & $\mathrm{E}$ & $\mathrm{P}$ & $\mathrm{S}$ & VG & VG & $G$ & $\mathrm{~S}$ & $\mathrm{E}$ & - & - \\
\hline SS & VG & VG & $E$ & $E$ & - & VG & $\mathrm{E}$ & $\mathrm{E}$ & $E$ & VG & $E$ & $E$ & $\mathrm{E}$ \\
\hline TDS & - & $\mathrm{P}$ & $\mathrm{P}$ & $E$ & $\mathrm{P}$ & $\mathrm{P}$ & $\mathrm{S}$ & $\mathrm{S}$ & $\mathrm{P}$ & $\mathrm{P}$ & VG & - & - \\
\hline COD & $\mathrm{P}$ & $E$ & VG & $E$ & $\mathrm{P}$ & $G$ & $\mathrm{E}$ & $\mathrm{E}$ & $\mathrm{S}$ & VG & $G$ & - & - \\
\hline BOD5 & - & - & $E$ & $\mathrm{P}$ & $\mathrm{P}$ & $\mathrm{P}$ & - & - & $\mathrm{P}$ & $E$ & - & $\mathrm{S}$ & $\mathrm{S}$ \\
\hline TOC & $\mathrm{P}$ & $\mathrm{S}$ & - & - & $\mathrm{S}$ & $G$ & $G$ & VG & $\mathrm{P}$ & - & - & - & - \\
\hline $\mathrm{TN}$ & $\mathrm{P}$ & $\mathrm{G}$ & $\mathrm{G}$ & $E$ & $\mathrm{P}$ & $\mathrm{P}$ & $G$ & $\mathrm{G}$ & $\mathrm{P}$ & $G$ & $E$ & $G$ & - \\
\hline TP & $E$ & $\mathrm{~S}$ & $E$ & $E$ & $S$ & $E$ & - & G & $E$ & VG & $\mathrm{G}$ & $G$ & - \\
\hline Ammonia & $\mathrm{P}$ & $\mathrm{P}$ & VG & VG & $\mathrm{S}$ & VG & $\mathrm{P}$ & $\mathrm{P}$ & $\mathrm{P}$ & $\mathrm{S}$ & $\mathrm{G}$ & $\mathrm{P}$ & - \\
\hline Conductivity & - & - & - & - & - & $\mathrm{P}$ & - & - & - & - & - & - & - \\
\hline E. Coli & $E$ & - & VG & $E$ & $\mathrm{BDL}$ & $E$ & - & $E$ & $E$ & VG & $E$ & $E$ & - \\
\hline
\end{tabular}


Table 10: EC Treatment Results of 11 different Facilities.

\begin{tabular}{|c|c|c|c|c|c|c|c|c|c|c|c|}
\hline Facility & A2 & C1 & G1 & G2 & ${ }^{*}$ LG1 & ${ }^{*} \mathrm{MV1}$ & P1 & P2 & ${ }^{*}$ P3 & SP1 & *SP2 \\
\hline $\begin{array}{l}\text { Process } \\
\text { Type }\end{array}$ & WP & WP & $\mathbf{W}$ & $\mathbf{W}$ & $\mathbf{w}$ & WP & $\mathbf{W}$ & $\mathbf{W}$ & WP & $\mathbf{W}$ & $\mathbf{W}$ \\
\hline $\begin{array}{l}\text { Tested } \\
\text { Samples }\end{array}$ & $1-2$ & 3 & 2 & 2 & 2 & $1-3$ & $1-3$ & $1-3$ & $1-3$ & $1-3$ & 1 \\
\hline Turbidity & VG & $G$ & $E$ & $E$ & - & $E$ & - & $\mathrm{S}$ & $E$ & $E$ & $E$ \\
\hline $\begin{array}{l}\text { Transmittanc } \\
\mathrm{e}\end{array}$ & $E$ & - & VG & $E$ & - & $E$ & - & $E$ & $E$ & VG & - \\
\hline TS & $\mathrm{S}$ & - & $\mathrm{G}$ & $\mathrm{E}$ & $\mathrm{P}$ & $\mathrm{S}$ & $\mathrm{S}$ & $\mathrm{G}$ & $G$ & $S$ & $\mathrm{E}$ \\
\hline SS & $\mathrm{P}$ & - & $E$ & $E$ & $\mathrm{P}$ & $E$ & $E$ & G & $E$ & $\mathrm{P}$ & $E$ \\
\hline TDS & $\mathrm{S}$ & - & $\mathrm{S}$ & $E$ & $\mathrm{P}$ & $\mathrm{P}$ & $\mathrm{P}$ & $\mathrm{S}$ & $\mathrm{S}$ & $G$ & VG \\
\hline COD & $G$ & $G$ & $E$ & $\mathrm{E}$ & $\mathrm{P}$ & $\mathrm{G}$ & $\mathrm{P}$ & $E$ & VG & $E$ & $E$ \\
\hline BOD5 & $\mathrm{P}$ & - & - & - & - & $S$ & - & $\mathrm{P}$ & $\mathrm{S}$ & - & - \\
\hline TOC & $\mathrm{P}$ & - & - & - & $\mathrm{P}$ & $\mathrm{P}$ & $\mathrm{P}$ & - & $\mathrm{S}$ & - & - \\
\hline TN & $\mathrm{P}$ & $\mathrm{G}$ & VG & $E$ & $\mathrm{P}$ & $\mathrm{S}$ & $\mathrm{P}$ & $E$ & $\mathrm{G}$ & $\mathrm{P}$ & $E$ \\
\hline TP & VG & - & $\mathrm{E}$ & $\bar{E}$ & $\mathrm{~S}$ & $E$ & VG & VG & $E$ & VG & $E$ \\
\hline Ammonia & $\mathrm{P}$ & - & $G$ & G & $P$ & $\mathrm{P}$ & $\mathrm{P}$ & $\mathrm{P}$ & $\mathrm{P}$ & $G$ & $E$ \\
\hline Conductivity & $\mathrm{P}$ & $\mathrm{P}$ & - & - & $\mathrm{P}$ & $\mathrm{P}$ & - & - & - & - & - \\
\hline E. Coli & $\mathrm{P}$ & - & $E$ & $E$ & BDL & $E$ & - & $E$ & $E$ & $E$ & $E$ \\
\hline
\end{tabular}


Table 11: Decision Matrix for Bench-scale Treatment Performance for Reducing Solids as Measured by Turbidity, Transmittance, and SS of various wash-water and operation types.

\begin{tabular}{|c|c|c|c|c|c|c|c|c|c|c|c|c|c|c|}
\hline SOLIDS & \multicolumn{2}{|c|}{ Settling } & \multicolumn{2}{|c|}{ C\&F } & \multicolumn{2}{|c|}{ DAF } & \multicolumn{2}{|c|}{ Centrifuge } & \multicolumn{2}{|c|}{$\mathrm{HC}$} & \multicolumn{2}{|c|}{ Screening } & \multicolumn{2}{|c|}{ EC } \\
\hline Operation Type & $\mathbf{W}$ & WP & $\mathbf{W}$ & WP & $\mathbf{w}$ & WP & $\mathbf{W}$ & WP & $\mathbf{W}$ & WP & $\mathbf{W}$ & WP & $\mathbf{w}$ & WP \\
\hline Potato & $\mathrm{P}$ & $\mathrm{P}$ & $E$ & $E$ & $E$ & VG & $E$ & $\mathrm{G}$ & $\mathrm{P}$ & $\mathrm{G}$ & $\mathrm{G}$ & $\mathrm{G}$ & $\mathrm{G}$ & $E$ \\
\hline Sweet Potato & $\mathrm{S}$ & - & $\mathrm{E}$ & - & VG & - & $\mathrm{E}$ & - & $\mathrm{P}$ & - & $\mathrm{P}$ & - & $\mathrm{E}$ & - \\
\hline Ginseng & $\mathrm{G}$ & - & $\mathrm{E}$ & - & $\mathrm{E}$ & - & $\mathrm{E}$ & - & $\mathrm{P}$ & - & $\mathrm{P}$ & - & $E$ & - \\
\hline SP2 and G2 (no soil control) & $G, P$ & - & $\mathrm{E}$ & - & $E$ & - & $E$ & - & $E$ & - & $\mathrm{P}$ & - & $E$ & - \\
\hline Carrot & - & G-P & - & $\mathrm{E}$ & - & VG & - & VG & - & $\mathrm{P}$ & - & $\mathrm{P}$ & - & $\mathrm{G}$ \\
\hline Mixed Veg & - & $\mathrm{G}$ & - & $E$ & - & VG & - & $\mathrm{E}$ & - & VG & - & $\mathrm{P}$ & - & $E$ \\
\hline Leafy Greens & $\mathrm{G}$ & - & $\mathrm{E}$ & - & VG & - & VG & - & $\mathrm{P}$ & - & $\mathrm{P}$ & - & $\mathrm{P}$ & - \\
\hline Apple & G-P & $P$ & VG & $E$ & - & VG & $G$ & $\mathrm{~S}$ & $P$ & $P$ & - & $P$ & - & $P$ \\
\hline
\end{tabular}

Table 12: Decision Matrix for Bench-scale Treatment Performance for Reducing COD of Various Wash-water and Operation Types.

\begin{tabular}{|c|c|c|c|c|c|c|c|c|}
\hline \multirow{2}{*}{$\begin{array}{l}\text { COD } \\
\text { Operation Type }\end{array}$} & \multicolumn{2}{|c|}{ C\&F with Settling } & \multicolumn{2}{|c|}{ DAF } & \multicolumn{2}{|c|}{ Centrifuge } & \multicolumn{2}{|c|}{ EC } \\
\hline & $\mathbf{W}$ & WP & $\mathbf{W}$ & WP & $\mathbf{W}$ & WP & $\mathbf{W}$ & WP \\
\hline Potato & $\mathrm{E}$ & $\mathrm{S}$ & $E$ & $\mathrm{~S}$ & VG & $\mathrm{S}$ & $\mathrm{E}$ & VG \\
\hline Sweet Potato & $E$ & - & VG & - & $\mathrm{P}$ & - & $E$ & - \\
\hline Ginseng & VG & - & VG & - & $\mathrm{E}$ & - & $E$ & - \\
\hline SP2 and G2 (no soil control) & G,VG & & $\mathrm{G}, \mathrm{E}$ & & $\mathrm{G}, \mathrm{E}$ & & $E$ & \\
\hline Carrot & - & $\mathrm{E}$ & - & $E$ & - & G & - & G \\
\hline Mixed Veg & - & VG & - & $\mathrm{G}$ & - & G & - & $\mathrm{G}$ \\
\hline Leafy Greens & $\mathrm{P}$ & - & $\mathrm{P}$ & - & $\mathrm{P}$ & - & $\mathrm{P}$ & - \\
\hline Apple & - & $P$ & - & $P$ & $P$ & $\mathrm{~S}$ & - & $\mathrm{G}$ \\
\hline
\end{tabular}

Table 13: Decision Matrix for Bench-scale Treatment Performance for Reducing TN \& TN of Various Wash-water and Operation Types.

\begin{tabular}{|l|c|c|c|c|c|c|c|c|}
\hline TN \& TP & \multicolumn{2}{|c|}{ C\&F with Settling } & \multicolumn{2}{c|}{ DAF } & \multicolumn{2}{c|}{ Centrifuge } & EC \\
\hline Operation Type & W & WP & W & WP & W & WP & W & WP \\
\hline Potato (TN;TP) & S;E & P;E & G;G & & P;VG & P;G & E;VG & G;E \\
\hline Sweet Potato & VG;E & - & G;VG & - & G;G & - & P;VG & - \\
\hline Ginseng & VG;E & - & G;E & - & G;VG & - & VG;E & - \\
\hline SP2 and G2 (no soil control) & E;-, VG;E & - & E;G, E;E & - & E;E, VG;VG & - & E;E, E;E & - \\
\hline Carrot & - & G;VG & - & G;S & - & S;P & - & S;- \\
\hline Mixed Veg & - & P;E & - & P;E & - & P;VG & - & S;E \\
\hline Leafy Greens & P;P & - & P;S & - & P;P & - & P;S & - \\
\hline Apple & - & P;E & - & P;E & P;P & P;P & - & P;VG \\
\hline P(<40\% removal), S (40-60\% removal), G (61-75\% removal), VG (76-90\% removal), E (>90\% removal), "-" not applicable/insufficient data \\
\hline
\end{tabular}


Table 14: Decision Matrix for Bench-scale Treatment Performance for Reducing E.Coli of Various Wash-water and Operation Types.

\begin{tabular}{|c|c|c|c|c|c|c|c|c|}
\hline E.Coli & C \& F v & ettling & & & $\mathrm{Cel}$ & & & \\
\hline Operation Type & $\mathbf{w}$ & WP & $\mathbf{W}$ & WP & $\mathbf{W}$ & WP & $\mathbf{w}$ & WP \\
\hline Potato (TN;TP) & $E$ & $E$ & $\mathrm{E}$ & $E$ & $\mathrm{P}$ & VG & $E$ & $\mathrm{E}$ \\
\hline Sweet Potato & VG & - & VG & - & VG & - & $E$ & - \\
\hline Ginseng & VG & - & VG & - & $E$ & - & $E$ & - \\
\hline SP2 and G2 (no soil control) & $\mathrm{G}, \mathrm{E}$ & - & $E ; E$ & - & $P ; E$ & - & $E$ & - \\
\hline Carrot & - & $E$ & - & - & - & - & - & - \\
\hline Mixed Veg & - & $E$ & - & $\mathrm{E}$ & - & $E$ & - & $E$ \\
\hline Leafy Greens & $\mathrm{BDL}$ & - & $*$ & - & $\mathrm{BDL}$ & - & $*$ & - \\
\hline Apple & $*$ & - & $*$ & $E$ & $*$ & $E$ & $*$ & $E$ \\
\hline
\end{tabular}

